\title{
Integrated supply of stemwood and residual biomass to forest-based biorefineries
}

\author{
Jonas Joelssona, Fulvio Di Fulviob,c, Teresa De La Fuentec, Dan Bergströmc, Dimitris Athanassiadis ${ }^{c}$ \\ a SP Processum AB, Örnsköldsvik, Sweden; ${ }^{b}$ Ecosystems Services and Management Program, International Institute for Applied Systems Analysis, \\ Laxenburg, Austria; ' Department of Forest Biomaterials and Technology, Faculty of Forestry, Swedish University of Agricultural Sciences, Umea, Sweden
}

Corresponding author. Teresa de la Fuente, Department of Forest Biomaterials and Technology, Faculty of Forestry, Swedish

University of Agricultural Sciences, 90183 Umeå, Sweden. Email: teresa.de.la.fuente@slu.se

Forest biomass may increasingly become demanded as raw materials for a wide range of products in the developing bioeconomy. Along with a constant pressure on forestry to increase its productivity, this development has led to the search for new procurement methods and new assortments. The present study assessed innovative supply chain practices, with a particular focus on the integrated supply of stemwood and residual tree parts. The assortments considered included tree sections, long tops, saw logs with stump cores and small whole trees from thinnings. The assessment included geographically explicit modelling of the supply chain operations and estimation of supply cost and energy use for three industrial locations in Northern Sweden. The innovative supply chains were compared to conventional, separate, harvest of stem wood and logging residues.

We conclude that integrated harvest of tops and branches with stem wood assortments, as well as whole-tree harvest in early thinnings, has a significant potential to reduce the supply cost for the non-stem wood assortments. Stump wood generally remains the most expensive assortment. The energy use analysis confirms earlier research showing that the energy input is relatively small compared to the energy content of the harvested feedstock.

Keywords: wood supply chain; forest fuels; harvesting system; forest feedstock assortment; supply cost; energy use

\author{
Acronym list \\ $\underline{\text { Locations }}$ \\ $\mathrm{UME}=\mathrm{Umeå}, \mathrm{ORN}=$ Örnsköldsvik, $\mathrm{STO}=$ Storuman \\ Supply systems
}

$A=$ conventional forestry regime and separated supply system options, $B=$ conventional forestry regime and integrated supply system options, $\mathrm{C}=$ biomass-dedicated and integrated supply system options

Forest treatments

$\mathrm{PCT}=$ pre-commercial thinning, $\mathrm{FT}=$ first thinning, $\mathrm{ST}=$ second thinning, $\mathrm{FF}=$ final felling, $\mathrm{ET}=$ energy thinning

Assortments

$\mathrm{SL}=$ sawlogs, $\mathrm{PL}=$ pulpwood, $\mathrm{LR}=$ logging residues, $\mathrm{SP}=$ stumps, $\mathrm{RS}=$ roughly delimbed tree sections, $\mathrm{LT}=\operatorname{long}$ tops, $\mathrm{WT}=$ whole small trees, $\mathrm{BWT}=$ bundled whole small trees, $\mathrm{SPC}=$ stump core

$\underline{\text { Units }}$

$\mathrm{EUR}=$ Euro, $\mathrm{GJ}=$ Giga Joule, $\mathrm{m}^{3} \mathrm{o}-\mathrm{b}=$ solid $\mathrm{m}^{3}$ over-bark, $\mathrm{PM}_{0} \mathrm{~h}=$ productive machine hours excluding delays, $\mathrm{PM}_{15} \mathrm{~h}=$ productive machine hours, $\mathrm{t}=$ oven dry tonne 


\section{Introduction}

The harvest of roundwood in Sweden has increased continuously since the early 20th century, while at the same time the forest stock has increased as a result of active forest management. Swedish forestry has developed into an efficient supplier of stemwood to pulp mills and sawmills and its productivity has improved through mechanization and technical development.

Several driving forces are currently affecting the forest industry (Sörensson \& Jonsson 2014). The demand for graphical paper is declining on several markets and the Swedish industry is encountering new competition from regions with fast-growing feedstock. At the same time, concerns about climate change and about the security of supply of fossil resources have acted to drive a search for new forest-based concepts for the production of material, energy and chemical products. Special attention has been paid to the concept of biorefining, where several products are co-produced in order to optimally utilize different fractions of the feedstock. This could lead to new uses of stemwood as well as an increased demand for other tree parts.

The harvesting system presently dominating in Sweden is the cut-to-length (CTL) system, where the tree is delimbed and the stem is cut into logs of appropriate length in the forest and then extracted to road side. Coarse logs of good quality are supplied to sawmills while low quality and smaller-diameter logs in general are supplied to pulp mills. The harvest residues - tops and branches - have, increasingly, been recovered separately, mainly for the production of heat and power. Tree stumps are recovered only at a very modest rate (Routa et al. 2013; Helmisaari et al. 2014). Certain adjustments in the harvesting operations have been made to facilitate the collection of the residues in order to improve productivity and fuel quality throughout the supply chain (Skogforsk 2010). The basic principles of the harvesting operations have, however, remained the same over the past 20 years. An alternative to present practice is to use supply systems where the residual biomass supply chain is integrated with the stem wood supply chain. Such systems were scrutinized in the late 1970s in Sweden, when the global oil crisis motivated increased efforts to utilize domestic forest biomass in order to secure the supply of energy (Whole Tree Utilization 1975-1980). However, the crisis was temporary and although the single-grip harvester was introduced in the early 80s together with the CTL system, the extraction of undelimbed wood (tree parts/sections) declined and finally fell out of use by the late 80s (Nordfjell et al. 2010). The current increasing demand for forest biomass has resulted in new developments in "integrated" forest harvesting systems (c.f. Berg et al. 2014). Understanding of the potential consequences of new practices can guide development efforts and increase the knowledge about future feedstock availability. The potential of the new integrated systems will depend on regional conditions such as forest composition and distribution, transportation distances and design of the full supply chain. To our knowledge, there are no studies aiming to quantify this potential for the selected systems.

The objective of the present study has been to assess the costs and energy use associated with supply chains that integrate the harvest of residue assortments into the stemwood supply chain. The integrated harvesting systems were compared to present conventional systems. The assessment was applied to three industrial locations suitable for biorefineries in Northern Sweden, using geographically explicit forest inventory data.

\section{Materials and Methods}

\section{System description}

An integral component of evaluating the forest feedstock supply and its implications is the understanding of the quantities of forest resources that might be available at any given price, i.e. a supply curve (Lundmark 2004). Based on observed productivity and energy use during forestry operations, we modeled the costs and energy used in the supply of conventional and new forest feedstock assortments. Three sites in Northern Sweden were selected for the study (Fig. 1). Two are on the coast, Umeå (UME) and Örnsköldsvik (ORN). Both have existing biomass-fired combined heat and power plants as well as large pulp mills and potential locations for new types of biorefinery industries. The third location, Storuman (STO), is located inland and is a potential location for a biorefinery or an industrial-scale hub for feedstock handling and upgrading before further transport to more distant industries. The three industrial sites are assumed to be located in the centre of the three cities and a supply area with a radius of $120 \mathrm{~km}$ around each of the locations was considered. 
Cost and energy use curves were calculated by modelling and adding together the costs and energy use for all operations from harvest to delivery to industry. Results are presented as supply cost curves and energy use curves for conventional and new forest feedstock assortments. The energy use and supply cost are given per oven dry tonne $(\mathrm{t})$ of feedstock delivered. Costs in Swedish currency (SEK) have been converted to euro using a conversion rate of 1 EUR $(€)=9.2$ SEK.

\section{$<$ Figure 1 left $><$ Figure 1 right $>$}

A conventional forestry regime was considered, in which a forest cycle was assumed to include precommercial thinning (PCT), first thinning (FT), second thinning (ST) and final felling (FF). The main assortments extracted from the forest in conventional forestry are sawlogs (SL) and pulpwood (PL). In addition, logging residues (LR) and stumps (SP) can be harvested. Two harvesting systems were compared within the conventional forestry regime (Systems A and B in Table 5). In system A stemwood and residual assortments are harvested separately while in system B stemwood and residual assortments are harvested together either as roughly delimbed tree sections (RS), long tops (LT) or sawlogs with a stump core (SPC) (see Berg et al. 2014). An alternative forestry regime was also considered which included an energy thinning (ET) instead of PCT. In ET, unprocessed tree sections from whole small trees (W'T) are extracted whereas in PCT the cut trees are left on site. The WT can be extracted loose or in bundles (BW'T) (System C in Table 5). The length of a forest cycle for both regimes was fixed to 95 years. The assortments considered are defined in Table 2 and the harvesting systems are described in Table 5.

\section{$<$ Table $1>$}

To ensure comparability, all studied supply systems were assumed to follow a general scheme where harvested feedstock is forwarded to the roadside and then transported by truck to a terminal in the vicinity of the receiving industry. The distance between the terminal and the industry was set to $5 \mathrm{~km}$. LR were assumed to be chipped at the roadside before transport to the terminal. All the other assortments are transported untreated to the terminal where they are further processed before delivery to industry. We also considered two scenarios, I and II, for the terminal operations. In scenario I, PL and the pulpwood part of RS and LT assortments is separated from residues (bark, branches and tops) at the terminal by means of a chain flail delimber/debarker and the assortments obtained are separately supplied to the industry in the form of debarked PL and chipped residues. In scenario II, all material (pulpwood and residues) is chipped and delivered directly without sorting at the terminal. Assortments SP, WT, BW'T and SPC are chipped without sorting in both scenarios. The operations and associated dry matter losses for each supply chain are summarized in Table 3. Energy use for general stand management operations, such as soil preparation, planting, and PCT was not included in the analyses. The costs associated with these operations were included indirectly in the land owner compensation.

\section{$<$ Table $2>$}

$<$ Table $3>$

The stand density and timing for each treatment (Table 1) were chosen based on the recommendations of Karlsson (2013) and the Swedish Forest Agency (2008). The stand development and tree size characteristics at each treatment stage were based on inventoried sample stands dominated by pine and spruce and were selected to be representative of the study region (SFA 2008). For each stage of development, the characteristics of one pine dominated and one spruce dominated stand were averaged. The characteristics of the stands were based on Gustavsson (1974) for PCT (stands 301 and 501) and for early thinning (stands 303 and 502). Type stands in Bredberg (1972) were used for FT (stands 310 and 401) and ST (stands 217 and 224). For FF, stands were based on Herlitz (1975) (stands 154 and 451). 
In the alternative forest regime (system $\mathrm{C}$ ), the ET is performed at a later stage than the PCT, and the FT is also delayed. The impact of the ET on the subsequent thinning operations is uncertain and will depend on stand characteristics (Karlsson 2013). We assumed that the difference in yield between the FT with and without ET is negligible. We assumed that ET would be performed using the boom-corridor technique (Bergström \& Di Fulvio 2014).

\section{Allocation}

Several of the operations in this study yield two or more products and in order to determine the production cost and energy use for each of the products, process costs and energy use have to be allocated between them. Costs in systems B \& C were calculated for the full supply chains and allocated between the products based on the change in costs and energy use compared to a reference case (A). For example, in system B with integrated harvest of roundwood and residues, only the additional cost of the integrated operation compared to separate roundwood harvest was allocated to the residue fraction. The cost and energy use allocated to the roundwood fraction is identical in all three alternative supply systems. For conventional system (A), harvester costs or energy use were allocated between stemwood assortments on a mass basis, whereas no harvester costs or energy use were allocated to the SP and the LR. Since the stemwood is considered the main product, the felling and delimbing process is carried out essentially in the same way irrespective of whether the SP and LR are recovered or not.

\section{Geographical distribution}

In calculating the terrain transport distance, the Network Analyst module in ArcGIS was used, and a winding coefficient of 1.2 was applied to the geodetic distance, following Athanassiadis et al. (2009). Transportation distances according to the Swedish road network were used in the calculations of road transportation.

Forest biomass harvest was modelled based on data from the Swedish National Forest Inventory (SNFI). The SNFI data were merged with the SFA (2008) data to model the growth, the yearly harvestable surface and the volume represented by each forest inventory plot over years 2010-2019. Each plot was used as a silvicultural decision unit and contained information on its geographical coordinates $(\mathrm{X}, \mathrm{Y})$, the management (FT, ST or FF), and soil characteristics. For each plot, the annual average amount of feedstock available from harvesting operations was calculated as well as average costs for harvest, forwarding and transportation of the feedstock to a terminal followed by delivery to the end user. Therefore the supply curves represent a 10 year average. Within the $120 \mathrm{~km}$ radius area, 268 inventory plots were included for UME, 279 for ORN and 150 for STO. Of this number of plots, 30 plots for UME, 29 for ORN and 11 for STO were excluded because of environmental protection reasons. A separate dataset from the SNFI contained information for PCT and early ET stands, adding 32 plots for UME, 42 plots for ORN and 30 plots for STO. The biomass functions in Petersson (1999) and Petersson and Ståhl (2006) were used to estimate the amounts (t/ha) of roundwood, bark, branches, needles, tops and stumpwood including root system from the SNFI data. Broadleave stumps were excluded (i.e. assumed to be left on site).

\section{Available feedstock amounts}

The proportions of wood assortments were calculated according to Ollas (1980). The top diameter for SL and PL logs was fixed respectively at 12 and $5 \mathrm{~cm}$ under bark. The mass of LR at FF in system A was calculated as the sum of the mass of branches and tops. The RS mass was calculated as the sum of the PL, tops, and the respective portion of branch mass as in Table 4. The mass of LT in the ST was calculated as the sum of PL mass and tops and by adding branches according to Table 4. The LT mass in FF was calculated as the sum of PL and mass of tops. The amount of wood for each assortment was added to the bark proportion given in Table 4, in order to obtain the mass over bark of SL, PL, LR, RS, LT.

\section{$<$ Table $4>$}


The annual potential for harvesting W'T from ET stands was calculated in plots where the average height was between $5.5 \mathrm{~m}$ and $8 \mathrm{~m}$ and where the removal biomass exceeded $25 \mathrm{t} / \mathrm{ha}$. The WT and BWT mass was obtained as the sum of PL, tops, bark and total branches mass. Plots where the average height was between $2.0 \mathrm{~m}$ and $5.5 \mathrm{~m}$ and the removal biomass exceeded $10 \mathrm{t} / \mathrm{h}$ a were classified as PCT stands. The total SP mass was given in the inventory plots. The stump core mass (SPC) was calculated by multiplying the total stemwood mass (SL, PL, tops and bark) by 0.085, following Berg et al. (2014). Dry densities in Table 4 were used for volume-to-mass conversions.

\section{Cost functions}

The supply cost functions were composed of harvest cost, forwarding cost, landing operation cost, truck transport cost, terminal cost, cost of transport from terminal to industry, land owner compensation, overhead costs. The compensation per biomass unit ( $\mathrm{t}$ ) to landowners (i.e. the stumpage price for the stand) in a FT, a ST and a FF was based on actual local prices (Norra skogsägarna pers. comm., October 2013). The land owner was assumed to receive economic compensation for the removal of LR, but not for SP removal, as in current practices. The compensation paid to the land owner is lower for PL from thinnings than from FF due to the limited profitability of thinning operations. In a FT the PL compensation is $14.13 € / \mathrm{t}$, in the ST it is $29.35 € / \mathrm{t}$ and in a FF it is $59.78 € / \mathrm{t}$. The LR compensation from FF is $7.61 € / \mathrm{t}$ and WT as energy-wood do not provide any compensation to the landowner. An overhead cost of $2.72 € / t$ for administration of forest operations was added (Brunberg 2013).

\section{$<$ Table $5>$}

\section{Harvesting}

The time consumption for each machine and operation was expressed as $\mathrm{PM}_{15} \mathrm{~h} / \mathrm{t}\left(\mathrm{PM}_{15} \mathrm{~h}=\right.$ productive machine hours including delays shorter than 15 minutes).

The effective time consumption per tree for the harvesters was deterministically calculated by means of literature functions (Eq.1-11, Table 6). The time consumption formulas assumed ideal terrain condition (c.f. Berg, 1992). For the harvester's time consumption formulas, $50 \%$ pine and $50 \%$ spruce removal was assumed. In the case of harvesting RS in FT following ET (supply system C), the same time consumption per hectare as in system B was used.

\section{$<$ Table $6>$}

The stem volumes and densities of trees per hectare used as parameters for calculations of time consumption were based on the stands in Table 1. The time consumption per tree (Eq. 1-11) was divided by the total mass of assortments harvested in each operation (cf. Table 6, column 1) to obtain the time consumption per unit of mass $\left(\mathrm{PM}_{0} \mathrm{~h} / \mathrm{t}\right)$. The average mass of extracted SP was calculated according to Larsson (2011). The $\mathrm{PM}_{0}$ time was converted to $\mathrm{PM}_{15}$ by multiplying values by the coefficient 1.30 (Kuitto et al. 1994) for the harvesters and by multiplying by 1.33 in case of PCT (Ligné et al. 2005).

\section{Forwarding}

The time consumption for wood extraction with forwarders included a fixed terminal time (i.e. loading and unloading) added to a variable extraction time that was distance-dependent. The $\mathrm{PM}_{0} \mathrm{~h} / \mathrm{t}$ for each assortment and operation was calculated by means of Eq. 12-25 using the load sizes and models given in Table 7. The $\mathrm{PM}_{0}$ time for forwarders was converted to $\mathrm{PM}_{15}$ by multiplying the value by the coefficient 1.2 (Kuitto et al. 1994).

\section{$<$ Table $7>$}




\section{Landing operations}

The time consumption for a truck-mounted drum chipper for LR at the roadside was assumed to be 0.086 $\mathrm{PM}_{15} \mathrm{~h} / \mathrm{t}$ according to Karlsson (2010). In the case of pre-crushing the SP at the roadside, the productivity of a horizontal low speed shredder was assumed to be $0.050 \mathrm{PM}_{15} \mathrm{~h} / \mathrm{t}$ according to Bertilsson (2011), in this case also a wheel loader was included in the system.

\section{Road transportation}

In road transportation, standard $24 \mathrm{~m}$ long truck and trailer systems of 22-32 $\mathrm{t}$ (un-loaded) with a crane for self-loading were considered for all products. The gross mass was set to $60 \mathrm{t}$. The time consumption models were given by the sum of terminal activities (i.e. loading and unloading) and driving time (Table 8). The distribution of traveling speeds was set according to Fjeld (2012) and applied in the range 5-120 km (Eq. 2634) and the load sizes were set according to Table 8.

The $\mathrm{PM}_{0}$ time was converted into $\mathrm{PM}_{15}$ by adding a delay time of 8 min. per load, according to Nurminen and Heinonen (2007).

\section{$<$ Table $8>$}

\section{Forest machinery cost rate}

The hourly cost for each forest machine (excluding VAT) was analytically calculated in $€ / \mathrm{PM}_{15} \mathrm{~h}$ according to Harstela (1993) and Bergström \& Di Fulvio (2014a) (Table 9). Purchase prices for forest machines were obtained directly from machine dealers in Sweden. For a thinning harvester equipped with a boom-corridor head, the purchase price was assumed to be $30 \%$ higher than a conventional thinning harvester. For a small forwarder, the installation of compacting stakes was assumed to increase the purchase price by $5 \%$ compared to a normal one. Fuel and lubricant consumption values used are presented in Table 12 (c.f. energy calculation methods). Prices for diesel and lubricants were set to 1.29 and $2.59 € / 1$ (www.energy.eu/fuelprices).

\section{$<$ Table $9>$}

The operating cost for a bundler-harvester producing BWT was assumed to be $84 \%$ higher than a "medium sized forwarder" according to assumptions in Kärhä et al. (2011), giving $156.09 € / \mathrm{PM}_{15} \mathrm{~h}$. For a feller-puller for extraction of SP the operating cost was assumed to be a 36\% more than for a "large harvester" according to Berg et al. (2014), giving $160.00 € / \mathrm{PM}_{15} \mathrm{~h}$. A fixed relocation cost of $271.74 € /$ machine/relocation was considered for all machines which needed to be relocated using a truck (harvesters, forwarders, roadside chipper, shredder); the average relocation distance between harvested plots was assumed to be $25 \mathrm{~km}$; the relocation cost and distance was representative of the normal situation in the studied Region (cf. Di Fulvio et al. 2011).

\section{Road transportation cost rate}

The truck and trailer unit purchase prices were based on information from contractor companies (Table 10). The fixed hourly cost $\left(\mathrm{F}_{\mathrm{h}}\right)$, variable cost for driving $\left(\mathrm{V}_{\mathrm{km}}\right)$ and variable cost for the crane $\left(\mathrm{V}_{\mathrm{ld}}\right)$ (Table 10) were calculated according to Bergström \& Di Fulvio (2014a) and used for assessing trucking fixed $\left(\operatorname{Tr}_{\mathrm{f}}\right)$ and variable costs $\left(\operatorname{Tr}_{\mathrm{v}}\right)$ per tonne.

\section{$<$ Table $10>$}


The forest harvesting and road transportation cost models are presented in Appendix 1.

\section{Terminal operations cost rate}

For all the assortments a storage period of 1 month in the terminal before re-loading and transportation of 5 $\mathrm{km}$ to the end user was assumed and the storage cost for using the terminal area was calculated according to Table 11. Two different scenarios were considered for delivery from the terminal to the end user:

I) delivery of debarked PL and chipped residues;

II) all woody material delivered after chipping (i.e. no PL debarking or delimbing);

In terminal scenario I: PL, RS and LT were considered to be delimbed and debarked with a chain flail delimber/debarker at the terminal. After the debarking/delimbing, chipping of the residual fractions from RS and LT (bark, branches and tops) with a large crusher was assumed.

The costs per $\mathrm{t}$ for a chain flail delimber/debarker were obtained by actualizing the cost figures in the literature with an inflation rate of $79 \%$. The same delimbing/debarking cost per $t$ was assumed for logs and residues (bark, branches, tree tops) (cf. Table 11). In terminal scenario II: PL, RS, LT were considered to be chipped directly (i.e. no debarking/delimbing) with a large disc chipper. In both terminal scenarios, WT and BWT were considered to be chipped directly at the terminal with a large disc chipper, without delimbing/debarking; the cost of chipping WT was assumed to be the same as for RS, and for BWT was assumed to be the same as for PL (c.f. Table 11). For SP it was considered that crushing was conducted in the terminal using a large crusher. For pre-crushed SP, it was considered that refining to smaller dimensions was achieved by means of a large crusher. The cost of sieving the SPC from SL was based on industrial figures for bucking the logs using a large saw blade driven by a $11 \mathrm{~kW}$ electric motor (cf. Table 11). All PL logs obtained in the terminal were assumed to be re-loaded onto trucks and trailers, while woodchips were assumed to be re-loaded into container trucks with capacities according to Table 8, in both cases the re-loading was assumed to be undertaken with a front wheeled loader with costs as in Table 11. The final transportation to the end user was assumed to take the same time for all trucks and calculated as $0.37 \mathrm{PM}_{15} \mathrm{~h} / \mathrm{load}$, as the time required for trucks to be driven from the terminal to the industry (i.e. no unloading cost at industry is included). The final transportation costs were calculated according to Table 11.

$<$ Table $11>$

\section{Energy use functions}

The energy use was calculated for each assortment supply chain in each location applying a life cycle perspective. A number of assumptions were made when defining the energy use functions:

- Average relocation distance of machinery and workers between sites was set to 25 kilometers.

- Trucks were assumed to be fully loaded for transport, with empty returns. The number of truck transports needed from each harvesting site was rounded to an integer number assuming that a truck could transport $10 \%$ more than its nominal capacity.

- The loading/unloading time for forestry machinery from/to a truck was assumed to be 8 minutes.

- The energy content of lubricants was assumed to be the same as the energy content of diesel.

- Each working day was considered to be 8 hours.

- Energy and materials needed for construction and maintenance of machinery, forestry roads, and ancillary materials were not included in the analysis.

\section{Energy functions}

The energy use was calculated per assortment in liters of diesel per t according to the equation below:

$$
E=T w+T m+L m+H a+H a f p+F o+E x+C c+L s+C h+T r+T o \text { (Eq. 35) }
$$


Where:

- $\quad T w$ is the fuel consumption for transporting workers to and from the harvesting site $(\mathrm{l} / \mathrm{t})$

$$
T w=\frac{2 \times D \times p f c \times W d \times N h s}{m}(\text { Eq. 36) }
$$

$D$ : distance from one harvesting site to the next harvesting site $(\mathrm{km}) ; p f c$. fuel consumption of a pick-up truck $(0.11 \mathrm{l} / \mathrm{km}) ; W d$ : number of working days needed to harvest a site (rounded up to the closest integer number); Nhs: number of harvesting sites in each inventory plot; $m$ : assortment removal mass of the yearly harvesting area in each inventory plot with total material losses $(t)$.

- $\quad T m$ is the fuel consumption for transporting machinery to and from the harvesting site $(l / t)$

$$
T m=\frac{D \times t f c \times N h s}{m}(\text { Eq. 37) }
$$

tfc. fuel consumption of a truck while driving $(0.56 \mathrm{l} / \mathrm{km})$

The total "Tm" allocated to each assortment was obtained by multiplying "Tm" by the number of machines involved in extraction of that assortment.

- $\quad L m$ is the fuel consumption by loading/unloading of machinery $(1 / t)$

$$
L m=\frac{2 \times t \times m f c \times N h s}{m}(\text { Eq. 38) }
$$

t. time to load and unload the machine from the truck; $m f c$ : machine fuel consumption $(1 / \mathrm{h})$;

The total " $L m$ " allocated to each assortment was obtained by adding together the " $L m$ " of all the machines involved in the extraction of that assortment.

- The fuel consumption $(1 / \mathrm{t})$ for harvesting and processing with harvester $(H a)$, harvesting with fellerpuller (Hafp), forwarding $(F o)$, excavating SP $(E x)$, coarse crushing $(C c)$, loading SP to shredder $(l s)$ and chipping $(C h)$, was obtained by multiplying the operational time consumption $\left(\mathrm{PM}_{15} \mathrm{~h} / \mathrm{t}\right)$ by the respective hourly fuel consumption $(\mathrm{l} / \mathrm{h})($ Table 12$)$ as in the following example:

$$
H a=h p \times h f_{c}
$$

$H a(1 / t)$ : fuel consumption of harvesting and processing with harvester; $h p$ : harvester time consumption for each assortment $\left(\mathrm{PM}_{15} \mathrm{~h} / \mathrm{t}\right) ; h f c$. harvester hourly fuel consumption $(\mathrm{l} / \mathrm{h})$

- $\quad \operatorname{Tr}$ is the fuel consumption for road transportation $(l / t)$

$$
\operatorname{Tr}=\text { driving } f\left(\text { load }, \text { unload } f c=\frac{(2 \times \operatorname{Trdist} \times t f c+l t f c \times T t) \times n \times N h s}{m}(\text { Eq. 39) }\right.
$$

$T r_{\text {dist }}$ road transportation distance from the harvesting site to industry $(\mathrm{km})$; Iffc fuel consumption for loading and unloading a truck $(7.70 \mathrm{l} / \mathrm{h}$ ); Tt. truck terminal time (h/load, unload and complementary activities); $n$ : number of trucks needed at each harvesting site to transport the assortments.

To is the fuel consumption during terminal operations. 
Fuel and lubricant consumption by forestry machinery and machinery in terminals was based on figures from the literature, according to Tables 12 and 13. The fuel consumption by trucks was assumed to follow Lindholm and Berg (2005), the fuel consumption by the pick-up truck was based on Fuel economy (2014). The lubricant consumption of trucks and pick-up trucks was assumed to be $0.2 \%$ of the fuel consumption (Lindholm et al. 2010).

$<$ Table $12>$

$<$ Table $13>$

The energy use for each supply chain is expressed as a percentage of the energy content of the delivered material. The energy content of wood was calculated on a lower heating value (LHV) basis. Assuming a LHV of $17.3 \mathrm{GJ} / \mathrm{t}$ for all biomass assortments and $35 \mathrm{GJ} / \mathrm{m}^{3}$ for diesel.

\section{Sensitivity analysis}

Important parameters of the study were varied in a sensitivity analysis. In the integrated harvesting systems it was assumed that there were no losses of branches on site when handling LT. Technical solutions may need to be developed in order to release some portion of the logging residues (eg. needles) at the harvesting site so as not to compromise the soil fertility, especially during thinnings (cf. Egnell 2011). Rough delimbing heads are under development for use in ET; it could be expected that 10-15\% of the total biomass can be left on site when harvesting W'T in ET (c.f. Bergström \& Di Fulvio 2014b).

- Variation 1: Assume harvesting losses of $20 \%$ of the residue part and from the LT in system B-C in the ST and FF.

If residues are harvested and transported as loose WT or LT, usually it is not possible to reach the maximum load capacities of trucks, due to the material's bulkiness. Therefore, the trucks for W'T and LT in B-C could be equipped with compacting stakes to increase the biomass density for road transportation.

- Variation 2: Assume an increase in trucking load capacity of $25 \%$ and $15 \%$, respectively, for WT and LT. An extra investment of 50,000 € on the purchase price of the LR truck and trailer unit is added.

For some of the machinery included in the innovative systems it was not possible to calculate analytically the costs, and their operating costs were based on assumptions, due to the fact that the machinery is still a prototype (bundle-harvester) or at the concept stage (feller-puller). Similarly, the productivity of such new machines is uncertain. The productivity assumed for a feller-puller was obtained from a simulation study. When comparing simulation results to field studies, overestimates of productivities of ca. $15 \%$ were found (eg. Sangstuvall et al. 2011). This is due to possible simplification of working environments in simulations compared to real forests. In the case of a bundler-harvester it was assumed that the machinery would be able to operate with the same efficiency as a boom-corridor harvester, which is an expected evolution of current machinery (c.f. Bergström \& Di Fulvio 2014b). However, as recently observed by Björheden and Nuutinen (2014), the productivities of a novel prototype of bundle-harvester doubled compared to the previous version, and the current level is ca. 15\% lower than the one considered in our study. However, a significant increase in productivity can be expected in future when the machine is also equipped with a head for boomcorridor thinning (c.f. Sangstuvall et al. 2011). Increased hourly costs and reduced productivity would both have a similar impact on the costs per $t$.

- Variation 3: Increased cost by $20 \%$ for operation of feller-puller (integrated log and SPC harvest) and bundle-harvester (integrated bundling and harvesting of W'T in ET).

\section{Results}

The three locations differ mainly in the total feedstock amount that could be produced: $1.3 \mathrm{Mt} / \mathrm{yr}$ for STO, $2.1 \mathrm{Mt} / \mathrm{yr}$ for UME and $2.3 \mathrm{Mt} / \mathrm{yr}$ for ORN, with supply system A (Table 14). The distribution between 
different assortments was, on average, 41\% SL (including bark), 25\% PL (including bark), 12\% LR and 20\% SP, for supply system A and differs only by a few percentage points between the three locations.

The supply of LR via supply system B increased the amount of residues compared to system A by $25 \%$ for ORN (UME: $15 \%$, STO: 34\%). The harvest of small trees during energy thinnings in supply system $\mathrm{C}$ adds $84000 \mathrm{t} / \mathrm{yr}$ for ORN (UME: 77000t/yr, STO: $86000 \mathrm{t} / \mathrm{yr}$ ). The contribution of W'T was comparatively large for the STO case, considering that the total feedstock amount was much smaller for STO than for UME and ORN. SPC harvest delivers only about $20 \%$ of the stump biomass, compared to conventional SP harvest.

$<$ Table $14>$

\section{Supply cost by assortment}

The total costs for the $120 \mathrm{~km}$ radius supply area for the ORN case is given in Table 15. Combing data from Tables 14 and 15 gives that the assortments with the highest supply cost are SP and SPC with, on average, $12 \%$ and $10 \%$ higher supply cost than PL. For SP, road transportation $(29 \%)$ and forwarding $(27 \%)$ accounted for the largest cost shares, while increased harvesting cost accounted for the largest cost share $(55 \%)$ for SPC. A small reduction in the productivity of the harvester may result in a high specific cost allocated to the SPC. LR supply cost was $12 \%$ lower than for PL, on average. The largest LR cost components were forwarding (31\%) and road transportation (22\%). RS and LT averaged a supply cost 7\% and 15\% lower, respectively, than for PL in system A. The largest cost components for RS are the transportation (29\%) followed by forwarding (19\%) and harvest (18\%). For LT, land-owner compensation accounted for $32 \%$, transportation for $29 \%$ and terminal operations for $18 \%$ of the cost. The cost of procuring WT is similar to that for RS or LT, and it is $5 \%$ lower than for PL. The main cost components in this case are road transportation (30\%) and harvesting (29\%). The supply cost of BWT is $15 \%$ lower than PL, and harvesting represents $42 \%$ of total costs.

\section{$<$ Table $15>$}

\section{Pulpwood}

The cost and energy use curves for supply of PL to the three locations are shown in Figure 2. The PL cost and energy use are, by definition, the same in all systems A-C. The costs excluding land-owner revenue are highest for FT and lowest for FF, which is expected due to the larger amounts harvested - and thus higher productivity of the machines - in FF. When landowner compensation is included, costs are similar for all three types of harvesting operations, in the range 85-100 $€ / t$ for the main part of the curve. Energy use in the supply accounts for about $1.5-3 \%$ of the energy content of the delivered feedstock.

The cost and energy use levels are similar between the three locations, and differences are mainly found in the total feedstock amounts available within the $120 \mathrm{~km}$ radius. There are also some differences in the distribution of the amounts between the different harvesting operations, where a relatively large share of the PL comes from FF in the UME case compared to STO, and with ORN falling somewhere between.

\section{$<$ Figure 2>}

\section{Tops and branches}

Supply cost curves for logging residues- tops and branches - obtained with the integrated supply system options B andC are shown in Figure 3, and compared to the corresponding curve for LR from FF with the conventional supply system $\mathrm{A}$. The curve for $\mathrm{B}$ and $\mathrm{C}$ is generally below the curve for $\mathrm{A}$. This means that more feedstock can be supplied at a given cost level. For example, at a marginal cost of $87 € / t, 100000 \mathrm{t}$ can 
be delivered by the conventional system A in UME and 240000 t by B-C. Similar results can be observed in the case of ORN and STO. The energy use curve is similar for the conventional (A) and the integrated systems $\mathrm{B}$ andC. The main part of the curve stretches between $2 \%$ and $6 \%$, which corresponds to 10-30 1 of diesel use per $\mathrm{t}$ of biomass delivered. The supplied amounts from individual plots are ranked by increasing supply cost and the supply cost curve thus forms a smooth, increasing line. The corresponding energy use for each plot is shown in the energy use curve. The energy use is not perfectly correlated to the supply cost and hence shows a more uneven curve. However, it follows the same general trend as the costs, indicating that the more expensive parts of the curve also require more energy.

The maximum amounts of delivered residual assortments from LT and RS are $275000 \mathrm{t}, 341000 \mathrm{t}$ and 203000 t per year for UME, ORN and STO, respectively. For conventional LR, the amounts are 239000 , $273000,151000 \mathrm{t}$ per year. The characteristics of the supply cost and energy use curves are similar between the three locations.

\section{$<$ Figure 3>}

\section{Stump wood}

The supply cost per $\mathrm{t}$ for a given harvest site is, on average, $3.3 €$ lower for SPC harvest than for conventional SP harvest $(112 € / \mathrm{t}$ vs. $115 € / \mathrm{t})$. The amount of biomass harvested with SPC harvest is, however, only $20 \%$ (on average) of the amount with conventional harvest. The supply cost curve for stump wood with SPC harvest therefore lies well above the curve for conventional harvest (Figure 4). The energy use curve for SPC, on the other hand, lies below the curve for conventional harvest. This can be explained by the fact that the SPC cost is dominated by increased costs of the harvesting operation, which has low energy intensity (energy use per cost) whereas for conventional SP harvest, the cost share is higher for operations with high energy intensity (such as transport). Energy use is about 2-3\% and 4-6\% of feedstock energy content, for SPC harvest and conventional SP harvest, respectively.

\section{$<$ Figure 4>}

\section{Energy thinning trees}

The harvested amounts are about $80.000 \mathrm{t} /$ year for all three locations. The alternative which involves bundling of the whole trees at harvest has markedly lower supply costs (typically below $87 € / \mathrm{t}$ ) than the alternative where the trees are handled loose (typically around or above $87 € / t$ ). In addition, energy use is lower for the bundling alternative by a little less than one percentage point and lies around $2-3 \%$ of the energy content of the delivered feedstock (Figure 5).

\section{$<$ Figure 5>}

\section{Chipping of all assortments without sorting (terminal alternative II)}

The total recovered amount of biomass is $8-12 \%$ larger in the conventional-separated supply system option A than in B and C, due to the much larger amount of SP wood extracted compared to SPC. If SP harvest is employed instead of SPC in system C, the harvested amount is larger for C than for A (Figure 6.). The supply cost for chipped feedstock lies mainly in the 75-110 $€ / t$ range (Figure 6 ). The integrated systems $B$ andC have markedly lower supply costs per t biomass compared to the conventional system A. Energy use figures lie around $2-4 \%$ of biomass energy content, as shown for the ORN case in Figure 7 . The cost variation is larger for the conventional case, which could be expected since PL and LR are handled independently and require different amounts of energy, whereas in the integrated system, the stemwood and residual biomass are handled together and hence are processed in the same way, and that results in a significant reduction in supply costs for large amounts. For example, if assuming a marginal cost of $87 € / \mathrm{t}$, approximately $1 \mathrm{Mt}$ more chips can be supplied in UME, ORN and STO together in system $\mathrm{C}$ than in the conventional case A, corresponding to an increase of approximately $330 \%$. 


\section{$<$ Figure 6>}

\section{$<$ Figure 7>}

\section{Sensitivity Analysis}

A $20 \%$ loss of residues in LT harvesting (Variation 1) would reduce the total potential by about $10 \%$. The cost curve of system $\mathrm{C}$ would shift upwards, but it would still be well below the system A curve except at high supply levels (Figure 8). Increased load capacities (Variation 2) for trucking of LT would significantly reduce the total supply cost of system $C$.

\section{$<$ Figure 8>}

Increased load capacity would also reduce the cost of unbundled WT (not shown in Figure 8), but it would still be higher than the BWT cost. Combining variation 2 with increased cost rate (variation 3 ) for the BWT system would result in more or less the same cost for BW'T and W'T. Hence, BW'T was used for all the system $\mathrm{C}$ curves in Figure 8. The increased cost rate for BWT in Variation 3 has a small impact on the overall supply curve (visible in the first half of the supply curve, mainly at around 350-600 thousand t). Increased cost rate for the SPC system on the other hand, would have a significant impact on the supply cost for stump wood in system C (visible in the latter part of the curve, at about 1050-1200 thousand $t$ ). The reason for this is that the harvesting cost is dominating the supply cost for SPC wood in system C and all of the extra harvesting cost is allocated to the SPC and nothing to the stemwood or branches.

Kons et al. (2014) show that terminals in Sweden are, on average, located $44 \mathrm{~km}$ from CHP, $66 \mathrm{~km}$ from pulpmills and $18 \mathrm{~km}$ from sawmills. The variable transportation cost used in our calculations was approximately $0.12 € / \mathrm{t}, \mathrm{km}$. A transportation distance of $66 \mathrm{~km}$ instead of $5 \mathrm{~km}$ would increase costs by 7.3 $€ / t$, compared with the total costs for chipped material of about $65-110 € / t$. This increase would, however, affect all assortments equally.

\section{Discussion}

The specific cost of individual operations and the amounts of feedstock extracted are key findings in the present analysis. The results indicate that there is a potential for decreasing the supply cost of forest biomass by using integrated harvest of stemwood with tree tops and branches, as compared to separate harvests. Also, small trees could be recovered from energy thinnings at an attractive cost, compared to conventional LR. SPC harvest has, on average, similar or slightly lower costs per $\mathrm{t}$ than SP harvest. However, it only results in about $20 \%$ of the stump biomass recovered during conventional stump harvest. On the other hand, SPC can be expected to be much cleaner than SP, which is typically contaminated with dirt, sand and rocks (Laitila et al. 2008; Athanassiadis et al. 2011). The SPC harvest system is probably the least developed of the systems studied, and the calculations therefore carry large uncertainties. Also harvest and bundling technologies in ET are under development, which leads to uncertainties in the input data used in the present study. ET could replace PCT fully or partially giving an additional benefit of avoided PCT costs. This was not included in our calculations, but could further improve the economics of energy thinning. However, it has been suggested that ET could affect the yield of FT. In modeling studies, the reduction in PL yield from FT was $8 \%$ in one case (Karlsson 2013). The actual effect on the yield will, however, depend on stand characteristics. No yield reductions in subsequent harvesting operations were taken into account here.

This paper provides a potential figure for the biomass supply based on geographically explicit forest inventory data along with projections of forest growth. Geographically explicit information was partly taken into account in the modeling of unit operations. In practice, each harvesting site will be unique, thus there will be variation and uncertainties that are not captured in this type of study. Harvested areas were derived from yield and harvest simulations for the period between 2010-2110, based on assumptions about the forest 
management cycle which were developed in the SKA-VB 08 study (SFA 2008). Losses were included only from handling and not from the decay of material during storage. For the tops and branches, we can expect that the innovative systems would benefit compared to the conventional ones from chipping at the terminal compared to chipping at the roadside, given the greater flexibility of operations in a terminal. A few months storage of chipped woody biomass can lead to microbial decay and significant losses (10-15\%) of dry matter (Jirjis 1995). Therefore, collecting and storing the unchipped residues at a terminal and adapting the chipping to the demands of the destination industry could lead to a reduction in dry matter losses and preserve the heating values and chemical properties. However, it will depend on how and for how long time unchipped residues are stored at terminals. Routa et al. (2015) found that the dry matter losses of unchipped logging residues can vary up to $3 \%$ per month.

The actual feedstock availability and cost to a given industry depends on the forest resources and supply systems, but also on a variety of factors such as the feedstock quality requirements, the kind of contracts negotiated and the competition for the feedstock. The supply curves created in this study are not sufficient to predict feedstock costs to individual industries. However, the selected methodology provides relevant information for understanding potential consequences with new practices and strikes an adequate compromise between general and site-specific results.

To generate curves for the systems studied, we adopted an approach where the conventional roundwood harvest operation was used as a reference and the changes in cost and energy use with new practices were allocated to the new assortments. Implicitly, the costs and energy use allocated to SL and PL were kept constant. This gives a good idea of the benefits (and costs) referable to the new practices, but it does not take into account for example how the changed costs affect the prices of different assortments on the market. A reduced total cost could, for example, be absorbed by entrepreneurs as increased profit or lead to lower saw timber prices, as well as cheaper feedstock prices for biorefining industries, depending on the market situation.

For practical reasons, the number of supply chain alternatives was limited. For example, it is common practice to chip LR at roadside as was assumed in the conventional system (Routa et al. 2013). For short transportation distances, however, it could be more efficient to transport the residues loose, or compacted, without chipping. Tahvanainen and Anttila (2011) report that up to $60 \mathrm{~km}$ distance to the heating plant transport of loose logging residues was the most cost competitive option. Also, in the conventional case we assumed that tops and branches were only recovered in final harvest, whereas in the innovative systems B and C, part of the tops and branches were also harvested during thinning operations.

Separate supply chains give greater flexibility in the supply as the demand for different assortments may vary. For example, in some Swedish regions, the demand for energy assortments is presently met by processing residues from pulp mills and sawmills, and there is little demand for forest fuels such as logging residues, whereas it is more attractive to harvest residues in other locations. Integrated supply of stemwood and residues appears to be an attractive option for industrial sites that process both types of forest feedstock. In addition, forest terminals may act as important hubs receiving integrated assortments and separating these for different users (Kons et al. 2014).

\section{Geographical differences}

The geographical area considered was limited to a $120 \mathrm{~km}$ radius around each of the three locations. For the coastal locations, the sea covers about half of this area, and hence the land area covered is smaller than for the inland location. Somewhat surprisingly, the inland location yielded the smallest feedstock amounts. There may be several reasons for this. First, part of the inland area falls in a mountainous region, with little or no forest growth (Swedish Forest Agency 2013). Second, the forest growth is much slower in the inland regions than in the coastal area, which means that the productivity of the forest is lower. Third, there may be a difference in age structure between the three areas. Indeed, a comparatively large share of the pulpwood in the inland area originated from thinning operations, relative to FF and the yields from ET were higher for the inland location 
than the coastal locations. However, no in-depth study was undertaken to examine the reasons for the geographical differences.

\section{Energy use}

Energy use and supply cost are fairly well, but not entirely, correlated. This is not surprising, since the operation of machines is a main factor in both supply cost and energy use. Almost all energy used in the operations is in the form of diesel. The amount of energy used corresponds to approximately $2-6 \%$ of the energy content of the delivered wood feedstock. This energy ratio agrees well with results reported from Ireland for logging residues and stumps with a similar conventional harvesting system (Murphy et al. 2014). For the innovative supply systems and when all material is chipped without prior separation, the corresponding energy ratio is about $2-4 \%$. These numbers are in relatively good agreement with other studies of supply chain energy use (De Jong et al. 2014). These studies, however, have mainly dealt with conventional assortments.

Hence, it can be concluded that the energy input to the forestry operations is relatively small compared to the energy value of the output products. It is still, however, one of the key contributors to costs and emissions in forestry operations, and hence, should not be ignored.

\section{Environmental considerations}

Although the use of energy wood can be considered environmentally beneficial in order to reduce greenhouse gas emissions compared to fossil fuel, it can have negative environmental implications such as changes in soil nutrient content and structure, and their possible effect on forest productivity, changes in water quality, and reduction of deadwood with the associated adverse consequences for biodiversity (Ferranti 2014). However, De Jong et al. (2014) indicated that the extraction of spruce residues in FF seems to have a minor impact on biodiversity compared to the total effects of other forest operations. In the present study, extraction of green residues has been considered. However, foliage may account for up to $50 \%$ of the nutrient content of the tree (Pelkonen et al. 2014). Foliage extraction could reduce nutrient availability in the soil whereas the extraction of SPC instead of SP would leave the root system in situ, mitigating the nutrient depletion and reducing soil disturbance (Berg et al. 2014). It has been observed for sensitive areas (eg. pine stands on mineral soils), that a decline in productivity can follow removal of logging residues (Egnell \& Valinger 2003). Harvesting operations may also result in soil disturbance, with adverse impacts (Walmsley and Godbold 2010; Ferranti 2014). LR are commonly placed on the ground to act as soil protection during harvesting operations, thereby limiting their potential use as feedstock. Simultaneous extraction of stemwood and residues could, however, reduce the total amount of driving over the terrain compared to the case where there is separate extraction (Walmsley and Godbold 2010). Other environmental synergies can also be identified between energy wood production and other ecosystem functions such as forest fire protection, reduction of pest risks and root rot (in the case of stump harvesting), and maintenance of nitrogen balance at sites with high nitrogen deposition (Ferranti 2014). Clearly, several environmental concerns should be addressed if forestry practices are changed. This would be an interesting topic for further studies.

\section{Feedstock properties in relation to industry quality demands}

Clean feedstock with low variability in properties is a general requirement of the biorefinery industry. For certain applications, some components of a tree are more valuable while some substances can be detrimental. For example, cellulose is the key component utilized in chemical pulping and in envisioned, future biochemical ethanol production, while ash components can often be detrimental in thermochemical applications. Different parts of the tree have different properties and it may be desirable to achieve a separation of the tree parts. With the conventional harvest system, fractionation of logs and residual assortments is undertaken at harvest. With the integrated systems, fractionation may have to be performed at an intermediate terminal or at the receiving industry. Potential disadvantages with the integrated systems are that there is no separation of valuable and less valuable components early in the chain; the feedstock is bulkier to transport and handle; and there are fewer opportunities to pass different fractions directly from harvest to different users. Advantages with the integrated systems may, on the other hand, include easier handling with lower risk of contamination of residual assortments; better control over comminution and 
fractionation if undertaken at a large-scale or at the site of the destination industry; lower risk of storage losses if comminution takes place later in the chain; potentially more efficient comminution and fractionation when performed at a large-scale at a terminal or industry site. The integrated systems would probably have an advantage in cases where the receiving industry accepts unsorted feedstock components.

\section{Conclusions}

Integrated harvest of tops and branches with stemwood assortments, as well as WT harvest during ET, has significant potential to reduce the supply cost of non-stemwood assortments. SP wood generally remains the most expensive assortment, and the SPC harvest system studied here does not reduce the cost. However, this system is the least studied and is particularly sensitive to uncertainties in the assumptions.

There is a cost reduction potential, but a change in practices is likely to require a steady demand for the residual assortments. This could be created by the expansion of biomass-based heat and power generation or through new biorefinery industries producing, for example, transportation fuels. Integrated supply would seem most interesting to industrial sites with the capacity to process both stemwood and residual assortments. In addition, increased use of terminals as hubs for fractionation and buffering of feedstock could be an interesting option which requires further study.

The energy use analysis confirms earlier research showing that the energy input is relatively small compared to the energy content of the harvested feedstock. The energy intensity curves largely follow the supply cost curves for the individual assortments, while the correlation is smaller for the combined supply curves.

Finally, changes in harvesting practices should be considered from an environmental perspective, especially when new practices lead to increased amounts of biomass being extracted. This was outside the scope of this study, but is an important field for future studies, along with full-scale field trials to verify the results of the study and to test the demand for new assortments.

\section{Acknowledgements}

This work was performed within the Forest Refine project and has been funded by the Botnia Atlantica program of the European Union regional development fund, the Region Västerbotten, the County Administrative Board of Västernorrland and the Regional Councils of Ostrobothnia and Central Ostrobothnia. The research leading to these results has been supported by the EU through the Marie Curie Initial Training Networks (ITN) action CASTLE, grant agreement no. 316020. The contents of this publication reflect only the authors' views and the European Union is not liable for any use that may be made of the information contained herein.

\section{References}

Athanassiadis D, Melin Y, Lundström A, Nordfjell T. 2009. Marginalkostnader för skörd av grot och stubbar från föryngringsavverkningar i Sverige [Marginal costs for harvesting of logging residues and stumps from regeneration fellings in Sweden]. SLU,Institutionen för skoglig resurshushållning, Sveriges

lantbruksuniversitet . Arbetsrapport vol. 261. ISSN 1401-1204. 25 p. (In Swedish) Available from: http://pub.epsilon.slu.se/4674/1/Arbetsrapport_261_Marginalkostnadskurvor.pdf

Athanassiadis, D., Lindroos, O. \& Nordfjell, T. 2011. Pine and spruce stump harvesting productivity and costs using a Pallari KH 160 stump-lifting tool. Scandinavian Journal of Forest Research, 26(5):437-445.

Berg S, Bergström D, Nordfjell T. 2014. Simulation of conventional and integrated stump wood and round wood harvesting systems and comparison of their productivity and cost. Int J Forest Eng. 25: 138-155.

Berg S. 1992. Terrain classification system for forestry work. The Forest Operations Institute of Sweden, Kista. 28 pp. ISBN 91-7614-078-4. 
Berg S, Lindholm E-L. 2005. Energy use and environmental impacts of forest operations in Sweden. J Cleaner Prod 13:33-42.

Berg, S. Nordfjell, T. \& Nurmi, J. 2014. Ground disturbance after stump extraction under different conditions. Proceedings of the Nordic Baltic Conference OSCAR14. Solutions for Sustainable Forestry Operations, June 25-27, 2014 NOVA Park Conference, Knivsta, Sweden.

Bergström D, Di Fulvio F. 2014.a Comparison of the cost and energy efficiencies of present and future biomass supply systems for young dense forests. Scandinavian Journal of Forest Research. 29: 793-812.

Bergström D, Di Fulvio F. 2014.b Evaluation of a novel prototype harvester head in early fuel-wood thinnings. Int J Forest Eng. 25: 156-170.

Bertilsson M. 2011. Grovkrossning av stubbar - en produktivitetsstudie. [Stump shredding - A study in productivity]. Arbetsrapport 335/2011. SLU, Sveriges lantbruksuniversitet, Institutionen för skoglig resurshushållning. ISSN 1401-1204. 26 p. (In Swedish with English abstract)

Björheden R, Nuutinen Y. 2014. Studie av Fixteri FX15a klenträdsbuntare. [Study of Fixteri FX15a small-tree bundling unit.] Arbetsrapport 819-2014, Skogforsk, Uppsala. The Forest Research Institute of Sweden. ISSN 1404-305X. 24 pp. (In Swedish with English abstract)

Bredberg CJ. 1972. Typbestånd I första gallring. [Type stands for the first thinning.] (Research Notes no. 55) Stockholm: Royal College of Forestry, Department of Operational Efficiency. Royal College of Forestry. Stockholm. 42 p. (In Swedish with English summary.)

Brunberg T. 1997. Underlag för producktionsnorm för engreppskördare i gallring. [Basic data for productivity norms for single-grip harvesters in thinning.] Redogörelse nr. 8, Skogforsk, The Forest Research Institute of Sweden, Uppsala. 18 p. (In Swedish with English summary)

Brunberg T. 2004. Underlag till produktionsnormer för skotare. [Productivity-norm data for forwarders.] Redogörelse från Skogforsk nr 3, Skogforsk The Forest Research Institute of Sweden, Uppsala. 11 p. (In Swedish with English summary)

Brunberg T. 2007. Underlag för produktionsnormer för extra stora engreppskördare i slutavverkning. [Basic data for productivity norms for extra large single-grip harvesters in final felling]. Redogörelse från Skogforsk nr 2, Skogforsk The Forest Research Institute of Sweden, Uppsala. 8 p. (In Swedish with English summary)

Brunberg T. 2013. Skogsbrukets kostnader och intäkter 2012. [Forestry costs and revenues in 2012.] Nr 82013. Skogforsk, Uppsala. Available from:http://www.skogforsk.se/sv/kunskap/db/2013/Skogsbruketskostnader-och-intakter-2012 (In Swedish). [Accessed on November 2013]

Danielsson BO, Liss JE. 2010. Långa toppar. [Long tops] Projekt SWX-Energi Rapport nr 5. Högskolan Dalarna och Karlstads Universitet. 38 p. (In Swedish) Available from: http://site.eventonline.se/ck_archive/106/files/Gamla_publikationer/SWX/5-Langa_toppar.pdf

De Jong J, Akselsson C, Berglund H, Egnell G, Gerhardt K, Lönnberg L,

Olsson B, Von Stedingk H. 2014. Consequences of an increased extraction of forest biofuel

in Sweden - a synthesis from the biofuel research programme 2007-2011. Summary of synthesis report. IEA Bioenergy Task 43, Report 2014/01. 37 p. The Swedish Energy Agency. Available from:

http://www.ieabioenergy.com/wp-content/uploads/2014/06/Consequences-of-an-increased-extractionof-forest-biofuel-in-Sweden-IEA-BIOENERGY-TR2014-1.pdf

Di Fulvio F, Bergström D, Nordfjell T. 2011. Skörd av skogsbränsle och/eller massaved i förstagallringar, vägkanter och på igenväxt åkermark. [Harvesting of fuel wood and/or pulpwood in early thinnings, roadsides and on overgrown arable land]. Swedish University of Agriculture Sciences, Department of forest resource management, Work report no. 343.36 p. (In Swedish with English abstract). Available from: http://pub.epsilon.slu.se/8633/1/Fulvio_Di_Fulvio_etal_20120315.pdf

Egnell G. 2011. Is the productivity decline in Norway spruce following whole-tree harvesting in the final felling in boreal Sweden permanent or temporary? Forest Ecology and Management. 261: 148-153. Egnell G, Valinger E. 2003. Survival, growth, and growth allocation of planted Scots pine trees after different levels of biomass removal in clear-felling. Forest Ecology and Management. 177: 65-74.

Eliasson L, Granlund P. 2010. Krossning av skogsbränsle med en stor kross. En studie av CBI 8400 hos Skellefteå Kraft. [Crushing of wood fuel with a large crusher. A study by the CBI 8400 in Skellefteå Kraft]. Arbetsrapport 716, Skogforsk,. Uppsala 6 p. (In Swedish). 
Eliasson L, Granlund P, Lundström H. 2012. Effekter på bränsleförbrukning, prestation och fliskvalitet av klenträd vs bränsleved som råvara vid flisning med en stor skivhugg. [Effects of raw material on performance, fuel consumption and chip quality of a large disc chipper.] Arbetsrapport 777, Skogforsk, Uppsala. 10 p. (In Swedish with English abstract).

Ferranti F. 2014. Energy wood: A challenge for European forests potentials, environmental implications, policy integration and related conflicts. European Forest Institute. EFI Technical Report 95, 2014. 157 p. Available from: http://www.efi.int/files/attachments/publications/efi_tr_95_ferranti_2014.pdf

Fjeld, D. 2012. Student exercises with GilleCalc in SPM0059. Operational planning and control. Swedish University of Agriculture Sciences, Department of Forest Resource Management.

Forsberg G. 2000. Biomass energy transport - analysis of bioenergy transport chains using life cycle inventory method. Biomass and Bioenergy 19:17-30.

Fueleconomy. 2014. Available at http://www.fueleconomy.gov [Accessed on December 2014]

Gustavsson R. 1974. Typbestånd i röjningsskog. [Type stands for cleaning.]) Research Note no.70. Royal College of Forestry, Department of Operational Efficiency. Garpenberg. ISSN 0585-332X. 58 p. (In Swedish with English summary)

Harstela P. 1993. Forest work science and technology, Part I. Silva Carelica, 25. 113 p.

Helmisaari H-S., Kaarakka L. \& Olsson B.A. 2014. Increased utilization of different tree parts for energy purposes in the Nordic countries, Scandinavian Journal of Forest Research. 29: 312-322,

Herlitz A. 1975. Typbestånd i slutavverkning. [Type stands for clear cutting]. TheRoyal College of Forestry, Department of operational efficiency. Research Notes 81. Garpenberg. (In Swedish).

Jirjis R. 1995. Storage and drying of wood fuel. Biomass and Bioenergy, 9: 181-190.

Jylhä P. 2011. Harvesting undelimbed Scots pine (Pinus sylvestris L.) from first thinnings for integrated production of kraft pulp and energy. Academic dissertation. University of Helsinki, Dissertationes Forestales, 133. Helsinki 2011. 73 p. ISBN 978-951-651-355-6.

Karlsson D. 2010. Prestation vid sönderdelning av GROT med olika typer av maskiner. [Productivity in chipping of logging residues with different types of machines.] SLU, Arbetsrapport 290, Institutionen för skoglig resurshushållning, Umeå. 44 p. (In Swedish with English abstract). Available from: http://stud.epsilon.slu.se/1840/1/Karlsson_D_100922.pdf

Karlsson L. (2013). Silvicultural regimes and early biomass thinning in young, dense pine stands. Doctoral thesis. Diss. Umeå : Sveriges lantbruksuniv., Acta Universitatis agriculturae Sueciae, ISSN 1652-6880 ; 2013:90, 67 p.

Kons K., Läspä O. 2013 Operational studies of a chain flail debarker. Bullettin 08.05.2013. Forest Refine Project, Biofuel Region, available at http:/ /www.biofuelregion.se [Accessed on September 2014]

Kons K, Bergström D, Eriksson U, Athanassiadis D, Nordfjell T. 2014. Characteristics of Swedish forest biomass terminals for energy. Int J Forest Eng. 25: 238-246.

Kuitto PJ, Keskinen S, Lindroos J, Oijala T, Rajamäki J, Räsänen T, Terävä J. 1994. Puutavaran koneellinen hakkuu ja metsäkuljetus. [Mechanized cutting and forest haulage.] Metsäteho Report 410. 38 p. (In Finnish with English summary).

Kärhä K. 2012. Comparison of two stump-lifting heads in final felling Norway spruce stand. Silva Fennica 46: 625-640.

Kärhä K, Jylhä P, Laitila J. 2011. Integrated procurement of pulpwood and energy wood from early thinnings using whole-tree bundling. Biomass and Bioenergy. 35: 3389-3396.

Laitila J, Ranta T, Asikainen A. 2008. Productivity of stump harvesting for fuel. Int J Forest Eng. 19: 37-47.

Laitila J, Asikainen A, Nuutinen Y. 2007. Forwarding of whole trees after manual and mechanized felling bunching in pre-commercial thinnings. Int J Forest Eng. 18: 29-39.

Laitila J, Kärhä K, Jylhä P. 2009. Time Consumption Models and Parameters for Off- and On-road Transportation of Whole-tree Bundles. Baltic Forestry 15: 105-114.

Laitila J, Väätäinen K. 2012. Truck transportation and chipping productivity of whole trees and delimbed energy wood in Finland. Croatian Journal of Forest Engineering. 33: 199-210.

Larsson KN. 2011. Stubbtransporter - en jämförelse av tre olika transportsystem. [Transport of stump wood a comparison of three different transport systems.] Arbetsrapport 320/2011. Sveriges lantbruksuniversitet 
Institutionen för skoglig resurshushållning. 36 p. (In Swedish with English abstract). Available from: http://stud.epsilon.slu.se/2591/1/Larsson_KN_110510.pdf

Ligné D, Eliasson L, Nordfjell T. 2005. Time consumption and damage to the remaining stock in mechanized and motor manual pre-commercial thinning. Silva Fennica 39: 455-464.

Lindberg D. 2008. Stubbtransporter och bränslekvalitet hos stubbved. [Stump transport and fuel quality in stump wood.] Arbetsrapport 220/2008. Sveriges lantbruksuniversitet. Institutionen för skoglig resurshushållning. 37 p. (In Swedish with English abstract). Available from: http://exepsilon.slu.se/2472/1/Arbetsrapport_220.pdf

Lindholm, E. L., and Berg, S., 2005. Energy requirement and environmental impact in timber transport. Scandinavian Journal of Forest Research 20(2):184-191.

Lindholm E L, Berg S, Hansson P A. 2010. Energy efficiency and the environmental impact of harvesting stumps and logging residues. European Journal of Forest Research. 129:1223-1235.

Liss JE, Johansson J. 2006. Utvärdering av nytt ekipage för vidaretransport av bränsleflis. [Evaluation of new trucks for transportation of fuel chips.] Högskolan Dalarna, Inst. för matematik, naturvetenskap och teknik, Garpenberg. Arbetsdokument nr 3, 23 p. (In Swedish) Available from: https://www.divaportal.org/smash/get/diva2:523013/FULLTEXT01.pdf

Lundmark R. 2009. Utbudet av biobränslen på kort och lång sikt. [The supply of biofuels in the short and long term] Report ER 2009:13. Swedish energy agency, Eskilstuna, Sweden. ISBN 1403-1892. 60 p. (In Swedish)

Murphy F., Devlin G., McDonnell K. 2014. Forest biomass supply chains in Ireland: A life cycle assessment of GHG emissions and primary energy balances. Applied Energy: 116:1-8.

Nordfjell T, Björheden R, Thor M, Wästerlund I. 2010. Changes in technical performance, mechanical availability and prices of machines used in forest operations in Sweden from 1985 to 2010. Scandinavian Journal of Forest Research. 25: 382-389

Nurmi J. 2007. Recovery of logging residues for energy from spruce (Pices abies) dominated stands. Biomass and Bioenergy. 31: 375-380.

Nurminen T, Heinonen J. 2007. Characteristics and time consumption of timber trucking in Finland. Silva Fennica. 41: 471-487.

Nurminen T, Korpunen H, Uusitalo J. 2009. Applying the activity-based costing to cut-to-length timber harvesting and trucking. Silva Fennica. 43: 847-870.

Ollas R. 1980. Nya utbytesfunktioner för träd och bestånd [New yield functions for trees and stands.] Forskningsstiftelsen Skogsarbeten, Ekonomi no 5. 4 p. Stockholm. (In Swedish)

Pelkonen P, Mustonen M, Asikainen A, Egnell G, Kant P, Leduc S, Pettenella D. (editors). 2014. Forest Bioenergy for Europe. What Science can tell us. European Forest Institute. 109 p. Available from: http://www.efi.int/portal/virtual_library/publications/what_science_can_tell_us/

Petersson H. 1999. Biomassafunktioner for tradfraktioner av tall, gran och bjork i Sverige [Biomass functions per tree fraction for Scots pine, Norway spruce and birch in Sweden] Working Rep. No. 59. Umea : Department of Forest Resource Analysis and Geomatics, Swedish University of Agricultural Sciences. 31 p. (In Swedish)

Petersson H, Ståhl G. 2006. Functions for below-ground biomass of Pinus sylvestris, Picea abies, Betula pendula and Betula pubescens in Sweden. Scandinavian Journal of Forest Research. 21:84-93.

Routa J, Asikainen A, Björheden R, Laitila J, Röser D. 2013. Forest energy procurement: State of the art in Finland and Sweden. Wiley Interdisciplinary Reviews: Energy and Environment. 2: 602-613.

Routa J, Kolström M, Ruotsalainen,Lauri Sikanen L. 2015. Precision measurement of forest harvesting residue moisture change and dry matter losses by constant weight monitoring. Int J Forest Eng. 26: 71-83

Skogforsk. 2010. Efficient forest fuel Supply Systems. Available from http://www.skogforsk.se/ess-rapport Stihl GmbH,www.stihl.se, [Accessed on 10/10/2013]

SFA-Swedish Forest Agency (Skogsstyrelsen), 2008. Skogliga konsekvensanalyser 2008. [Forest impact analyses 2008]. SKA-VB 08. Rapport 25. Available from: http://shop.textalk.se/shop/9098/art66/4646166-79b6f0-1812.pdf

SFA-Swedish Forest Agency (Skogsstyrelsen) 2012. Swedish Statistical Yearbook of Forestry 2012. Swedish Forest Agency, Jönköping, Sweden. 
Swedish Forest Agency (Skogsstyrelsen) 2013. Swedish statistical yearbook of forestry 2013. Swedish Forest Agency, Jönköping, Sweden. ISBN 978-91-87535-01-7.

Sukumara S, Faulkner W, Amundson J, Badurdeen F, Seay J. 2014. A multidisciplinary decision support tool for evaluating multiple biorefinery conversion technologies and supply chain performance. Clean Techn Environ Policy. 16:1027-1044

Sängstuvall L, Bergström D, Lämås T, Nordfjell T. 2011. Simulation of harvester productivity in selective and boom-corridor thinning of young forests. Scand. J. For. Res. 27: 56-73.

Södestrom J. 2006. Upparbetning av grot i semimobila terminaler. [Processing logging residues in semimobile terminals]. Delrapport inom projektet"Samverkan för utveckling och förädling av regionens outnyttjade skogsresurser”. Energidalen AB i Sollefteå. 27 pp. (In Swedish with English abstract)

Sörensson R, Jonsson A. 2014. Företag inom svensk massa- och pappersindustri [Companies within the Swedish pulp and paper industry.] VINNOVA Analysis VA 2014:08, September 2014, Swedish Governmental Agency for Innovation Systems, Stockholm, ISBN: 978-91-87537-120-2. 70 p (In Swedish with English abstract)

Tahvanainen T, Forss E. 2008. Individual tree models for the crown biomass distribution of Scots pine, Norway spruce and birch in Finland. Forest Ecology and Management. 255: 455-467.

Tahvanainen, T. \& Anttila, P. 2011. Supply chain cost analysis of long-distance transportation of energy wood in Finland, Biomass and Bioenergy, 35(8): 3360-3375

Valeur C. 2003. Papper och massa i Västerbotten och Norrbotten: [från handpappersbruk till processindustri]. [Paper and pulp in Västerbotten and Norrbotten: from handmade paper to industrial processes] Stockholm: Skogsindustrierna. Skogsindustriernas historiska utskotts skriftserie, 99-2494817-3. 312 p. (In Swedish)

Von Hofsten H. 2011. An interactive tool for system analysis. In: Skogforsk. 2010. Efficient forest fuel Supply Systems. Composite report from a for year R\&D programme 2007-2010. Uppsala, Sweden, Skogforsk. ISBN: 978-91-977649-4-0

Von Hofsten H, Granlund P. 2010. Effektivare transporter om stubbarna grovkrossas på avlägg. [Effective transportation of stumps pre-crushed at the forest landing.] Resultat från Skogfrosk nr. 2. Uppsala. 4 p. (In Swedish with English abstract)

Walmsley JD, Godbold DL. 2010. Stump harvesting for bioenergy- a review of the environmental impacts. Forestry 8: 17-38

Watson WF., Twaddle AA, Hudson JB. 1993. Review of Chain Flail Delimbing-Debarking. Int J Forest Eng. 4: 37-52

Wecalc, Wood Energy Calculations. Available at: http://woodenergy.sites.djangoeurope.com/conversion/ [Accessed on September 2014]

Wihersaari M. 2005. Greenhouse gas emissions from final harvest fuel chip production in Finland. Biomass and Bioenergy. 28: 435-43.

Åström SE. 1988. From tar to timber: studies in Northeast European forest exploitation and foreign trade, 1660-1860, Finnish Society of Sciences and Letters. ISBN 951653161X. 229 p. 
Table 1. Alternative forestry regimes considered in the analyses.

\begin{tabular}{|c|c|c|c|c|c|c|c|}
\hline \multicolumn{3}{|c|}{ Conventional } & \multicolumn{3}{|c|}{ Biomass } & \multirow[b]{2}{*}{$\begin{array}{l}\text { Initial } \\
\text { trees/h } \\
\text { a }\end{array}$} & \multirow[b]{2}{*}{$\begin{array}{l}\text { Remov } \\
\text { al } \\
\text { trees/h } \\
\text { a }\end{array}$} \\
\hline & $\begin{array}{l}\text { Removal } \\
\text { stem } \\
\text { volume } \\
\left(\mathrm{m}^{3} \mathrm{o}-\mathrm{b}\right)^{*}\end{array}$ & $\begin{array}{l}\text { Initial } \\
\text { trees/h } \\
\text { a }\end{array}$ & $\begin{array}{l}\text { Remov } \\
\text { al } \\
\text { trees } / \mathrm{h} \\
\text { a }\end{array}$ & $\begin{array}{l}\text { dedicate } \\
\text { d }\end{array}$ & $\begin{array}{l}\text { Removal } \\
\text { stem } \\
\text { volume } \\
\left(\mathrm{m}^{3} \mathrm{o}-\mathrm{b}\right)^{*}\end{array}$ & & \\
\hline $\begin{array}{l}P C T \\
(10\end{array}$ & & & & $\begin{array}{l}E T \\
(25\end{array}$ & & & \\
\hline years) & 0.003 & 10,000 & 7,500 & $\begin{array}{l}\text { years) } \\
F T\end{array}$ & 0.01 & 10,000 & 6,000 \\
\hline FT & & & & $(50$ & & & \\
\hline $\begin{array}{l}\text { (45 year) } \\
S T \\
\text { (70 }\end{array}$ & 0.05 & 2,500 & 1,000 & $\begin{array}{l}\text { years) } \\
S T \\
(75\end{array}$ & 0.02 & 4,000 & 2,500 \\
\hline $\begin{array}{l}\text { years) } \\
\text { FF }\end{array}$ & 0.16 & 1,500 & 800 & $\begin{array}{l}\text { years) } \\
\text { FF }\end{array}$ & 0.16 & 1,500 & 800 \\
\hline $\begin{array}{l}\text { (95 } \\
\text { years) }\end{array}$ & 0.3 & 700 & 700 & $\begin{array}{l}\text { (95 } \\
\text { vears) }\end{array}$ & 0.3 & 700 & 700 \\
\hline
\end{tabular}


Table 2. Definition of assortments.

\begin{tabular}{|c|c|c|}
\hline & Definition & $\begin{array}{l}\text { Silvicultural } \\
\text { treatment }\end{array}$ \\
\hline $\begin{array}{l}\text { Pulpwood } \\
(\mathrm{PL})^{*}\end{array}$ & $\begin{array}{l}\text { Delimbed small-diameter logs with bark with a top } \\
\text { diameter } \geq 5 \mathrm{~cm} \text { under bark (u-b). }\end{array}$ & FT, ST, FF \\
\hline $\begin{array}{l}\text { Logging } \\
\text { residues }(\mathrm{LR})^{*}\end{array}$ & $\begin{array}{l}\text { Tree-tops (diameter } \leq 5 \mathrm{~cm} \mathrm{u} \text {-b) and branches removed } \\
\text { from the stem at conventional round-wood harvest. }\end{array}$ & $\mathrm{FF}$ \\
\hline Stumps $(\mathrm{SP})^{\star}$ & $\begin{array}{l}\text { The stump left when a tree is cut including part of the } \\
\text { roots. }\end{array}$ & FF \\
\hline $\begin{array}{l}\text { Rough- } \\
\text { delimbed tree } \\
\text { sections } \\
(\mathrm{RS})^{\star \star}\end{array}$ & $\begin{array}{l}\text { Partly delimbed stemwood cut into sections ( } 50 \% \text { branch } \\
\text { mass is included). }\end{array}$ & FT \\
\hline $\begin{array}{l}\text { Long tops } \\
(\mathrm{LT})^{\star \star}\end{array}$ & $\begin{array}{l}\text { The pulpwood part of a stem (diameter } u-b \leq 12 \mathrm{~cm} \text { ) with } \\
\text { the tree-top and branches still attached. }\end{array}$ & ST, FF \\
\hline $\begin{array}{l}\text { Whole trees } \\
(\text { WT })^{\star *}\end{array}$ & $\begin{array}{l}\text { Small trees from thinning operations with top and all } \\
\text { branches still attached. }\end{array}$ & ET \\
\hline $\begin{array}{l}\text { Bundled } \\
\text { whole trees } \\
\text { (BWT) }\end{array}$ & $\begin{array}{l}\text { As whole trees but cut into sections which are } \\
\text { compressed and tied together into ca. } 0.5 \mathrm{~m}^{3} \text { solid } \\
\text { bundles at the harvest site. }\end{array}$ & ET \\
\hline $\begin{array}{l}\text { Stump core } \\
(\text { SPC })^{\star *}\end{array}$ & $\begin{array}{l}\text { The extension of the stem into the stump, which can be } \\
\text { cut out together with the lower part of the stem. }\end{array}$ & FF \\
\hline
\end{tabular}


Table 3. Summary of supply systems used. Dry matter losses for each operation are given as percentages (\%) in brackets. Assortments are abbreviated according to Table 2.

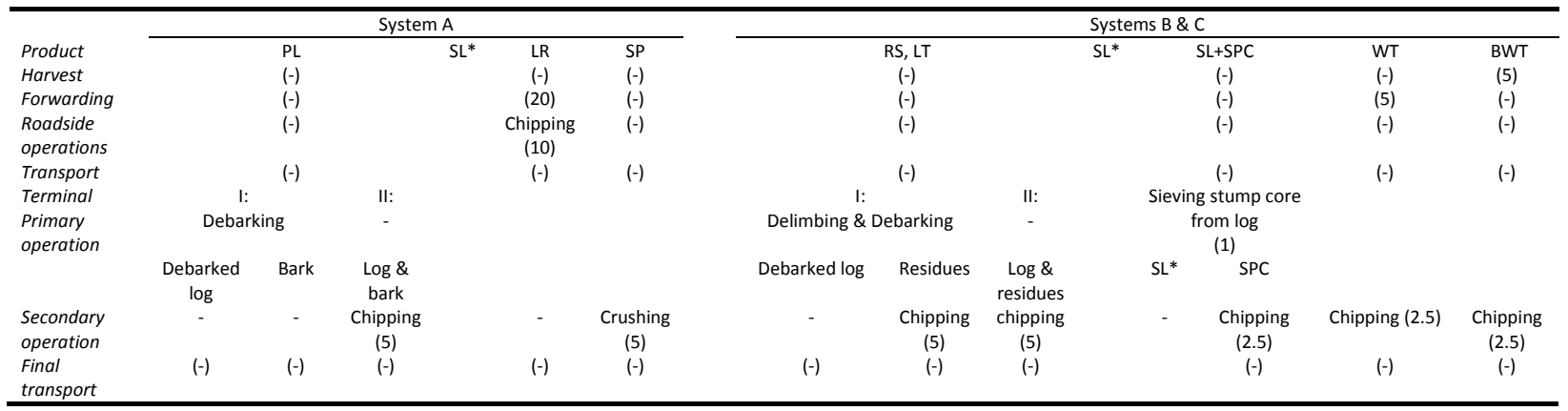

* Sawlogs were not further considered in the study. 
Table 4. Mass percentage of stem bark and branches used in the calculations for the different assortments (treatments are given in brackets) as well as dry densities assumed in the conversions.

\begin{tabular}{llll}
\hline & $\begin{array}{l}\text { Dry density } \\
(\text { ODkg/m³ solid })\end{array}$ & $\begin{array}{l}\text { Stem bark } \\
(\%)\end{array}$ & $\begin{array}{l}\text { Branches } \\
(\%)\end{array}$ \\
\hline SL & $400^{\mathrm{a}}$ & $43(\mathrm{ST}), 66(\mathrm{FF})$ & - \\
$\mathrm{PL}$ & $400^{\mathrm{a}}$ & $80(\mathrm{FT}), 43(\mathrm{ST}), 29(\mathrm{FF})$ & - \\
LR & $450^{\mathrm{a}}$ & 5 & 100 \\
RS & $410^{\mathrm{b}}$ & 100 & 50 \\
LT & $420^{\mathrm{a}}$ & $57(\mathrm{ST}), 34(\mathrm{FF})$ & $93(\mathrm{ST}$ pine), 81 (ST \\
& & & spruce) 59 (ST pine), 56 \\
& & - & $(\text { ST spruce })^{\mathrm{c}}$ \\
WT & $420^{\mathrm{a}}$ & - & - \\
SP & $452^{\mathrm{a}}$ & - & - \\
SPC & $410^{\mathrm{b}}$ & - & -
\end{tabular}

aaccording to the WeCalc calculation tool. ${ }^{\mathrm{b} C a l c u l a t e d ~ v a l u e .}{ }^{\mathrm{c}}$ The The percentage masses of branches were calculated using the Tahvanainen and Forss (2008) functions. 
Table 5. Description of the supply systems included into the analyses from the forest to the terminal: $A=$ conventional forestry regime and separated supply system options, $B=$ conventional forestry regime and integrated supply system options, $\mathrm{C}=$ biomass-dedicated and integrated supply system options.

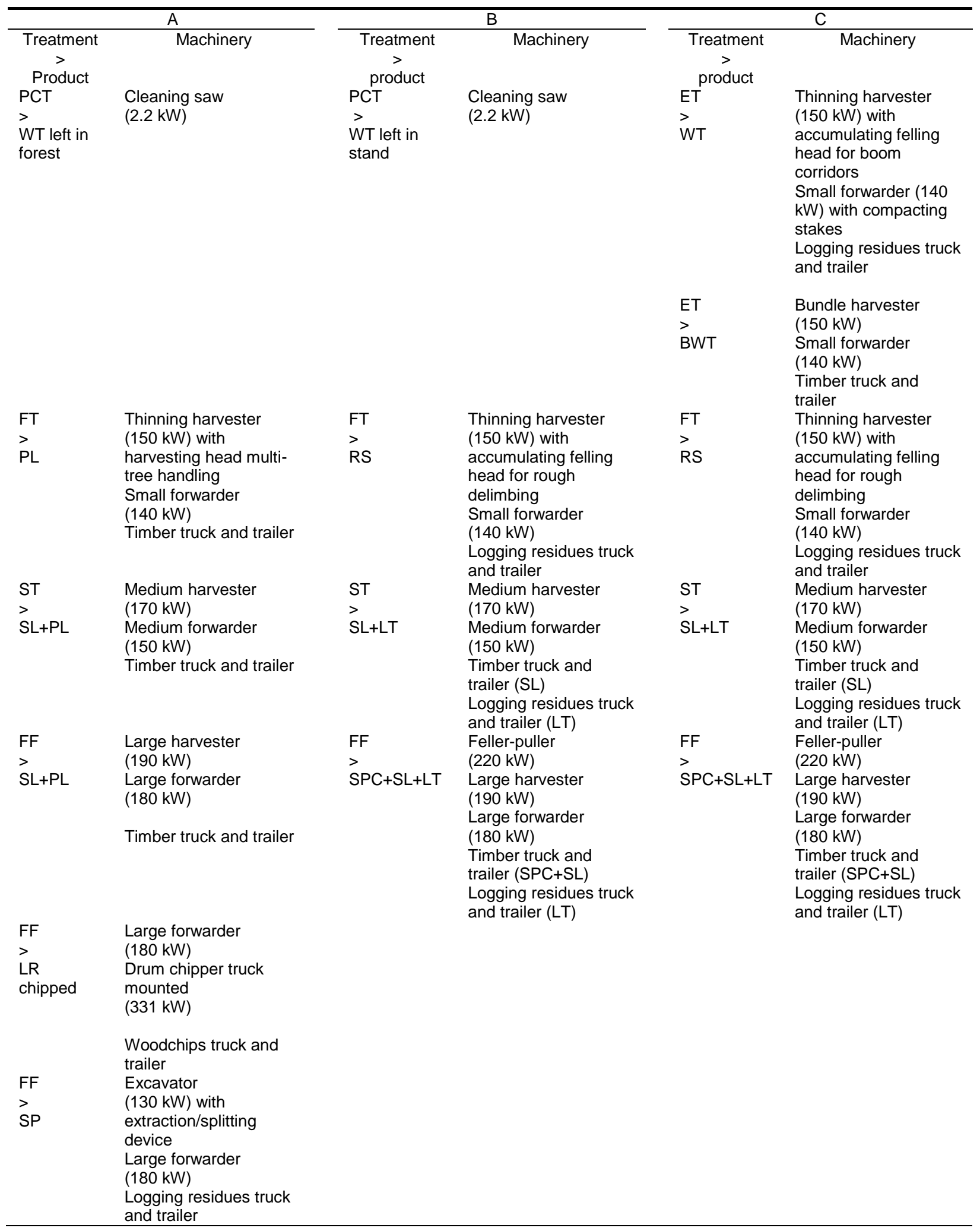




\begin{tabular}{ll}
\hline FF & Excavator \\
$>$ & $(130 \mathrm{~kW})$ with \\
SP pre- & extraction/splitting \\
crushed & device \\
& Large forwarder \\
& $(180 \mathrm{~kW})$ \\
& Shredder (328 kW) \\
& Grapple loader (120 \\
& kW) \\
& Woodchips truck and \\
& trailer \\
\hline
\end{tabular}


Table 6. Effective time consumption equations and parameters used for the harvesters.

\begin{tabular}{|c|c|c|c|}
\hline $\begin{array}{l}\text { Supply system } \\
\text { option/ Extraction } \\
\text { phase/Assortment }\end{array}$ & Equation Parameters & Eq. & Reference \\
\hline A/PCT/- & $\begin{array}{l}-4.83+0.000186 \times n_{b}+0.630 \times h_{b}+0.0466 \times\left(h_{b} / d_{b}\right) ;(\mathrm{PMOh} / \mathrm{ha}) \\
\mathrm{n}_{\mathrm{b}}=\text { number of trees per hectare before harvest }(\text { trees } / \mathrm{ha}), \mathrm{h}_{\mathrm{b}}=\text { average height of trees } \\
\text { before harvest, }(\mathrm{m}), \mathrm{d}_{b}=\mathrm{DBH} \text { before harvest, }(\mathrm{m})\end{array}$ & 1 & Ligné et al. (2005) \\
\hline $\mathrm{A} / \mathrm{FT} / \mathrm{PL}$ & $\begin{array}{l}6.0+35.6 \times m_{b}^{3}+4544 \times \frac{1}{n_{b}} ;(\text { Second } / \text { tree }) \\
\mathrm{m}^{3} \mathrm{~b}=\text { average stem volume before harvest, }\left(\mathrm{m}^{3}\right)\end{array}$ & 2 & Sängstuvall et al. (2011) \\
\hline $\mathrm{A} / \mathrm{ST} / \mathrm{SL}+\mathrm{PL}$ & $\begin{array}{l}{\left[4.3+\frac{1000000}{280.8 \times n_{r} \times\left[50 / n_{r}\right]}+{d m^{3}}_{r} \times 0.128+\frac{n_{a}}{1000} \times 23.45\right] \times 0.6 ;(\text { Second } / \text { tree })} \\
\mathrm{dm}^{3}=\text { removal stem volume under bark }\left(\mathrm{dm}^{3}\right), \mathrm{n}_{\mathrm{r}}=\text { number of removal trees per hectare } \\
(\text { trees/ha) } \\
\mathrm{n}_{\mathrm{a}}=\text { remaining trees after thinning per hectare }(\text { trees/ha) }\end{array}$ & 3 & Brunberg (1997) \\
\hline $\mathrm{A} / \mathrm{FF} / \mathrm{SL}+\mathrm{PL}$ & $\begin{array}{l}{\left[24.7+\frac{1000000}{364 \times n_{r} \times\left[0.8+\left(50 / n_{r}\right)\right]}+41 \times m_{r}^{3}\right] \times 0.646 ;(\text { Second } / \text { tree })} \\
\mathrm{m}^{3}{ }_{r}=\text { removal stem volume under bark }\left(\mathrm{m}^{3}\right)\end{array}$ & 4 & Brunberg (2007) \\
\hline A/FF/SP pine & $\begin{array}{l}11.8+e^{3.5+0.03 \times d_{s}} ;(\text { Second } / \text { stump }) \\
\text { ds }=\text { diameter at the stump }(\mathrm{cm})\end{array}$ & 5 & Larsson (2011) \\
\hline A/FF/SP spruce & $11.8+e^{3.38+0.03 \times d_{s}} ;($ Second $/$ stump $)$ & 6 & Larsson (2011) \\
\hline $\mathrm{B} / \mathrm{FT} / \mathrm{RS}$ & $6.04+38.7 \times m_{b}^{3}+5091 \times \frac{1}{n_{b}} ;($ Second $/$ tree $)$ & 7 & Sängstuvall et al. (2011) \\
\hline $\mathrm{B} / \mathrm{ST} / \mathrm{SL}+\mathrm{LT}$ a & $\left\{\left[4.3+\frac{1000000}{280.8 \times n_{r} \times\left[50 / n_{r}\right]}+\mathrm{dm}^{3} \times 0.128+\frac{n_{a}}{1000} \times 23.45\right] \times 0.6\right\} \times 0.82 ;($ Second $/$ tree $)$ & 8 & $\begin{array}{l}\text { Brunberg (1997) } \\
\text { Danielsson \& Liss } \\
\text { (2010) }\end{array}$ \\
\hline $\begin{array}{l}\text { B/FF/SPC+SL+ LT } \\
\text { feller-puller b, c }\end{array}$ & $8.4+\left\{\left[24.7+\frac{1000000}{364 \times \mathrm{n}_{\mathrm{r}} \times\left[0.8+\left(50 / n_{r}\right)\right]}+41 \times m_{r}^{3}\right] \times 0.646 \times 0.82 \times 0.53\right\} ;($ Second $/$ tree $)$ & 9 & $\begin{array}{l}\text { Berg et al. (2014) } \\
\text { Brunberg (2007) }\end{array}$ \\
\hline
\end{tabular}


$\mathrm{B} / \mathrm{FF} / \mathrm{SPC}+\mathrm{SL}+\mathrm{LT}$

Harvester ${ }^{b}$

$\left\{\left[24.7+\frac{1000000}{364 \times n_{r} \times[0.8+(50}\right.\right.$ $\left.\left.\frac{1000000}{364 \times n_{r} \times\left[0.8+\left(50 / n_{r}\right)\right]}+41 \times m^{3}\right] \times 0.646\right\} \times 0.82 \times 0.47 ;($ Second $/$ tree $)$

$1.05+\left[\left(0.862+12.2 \times m^{3}{ }_{b}+15434 \times \frac{1}{n_{b}}\right) \times 0.822\right] ;($ Second $/$ tree $)$
Brunberg (2007)

Danielsson \& Liss

11 Sängstuvall et al. (2011)

$\mathrm{m}^{3} \mathrm{~b}=$ average stem volume before harvest, $\left(\mathrm{m}^{3}\right), \mathrm{n}_{\mathrm{b}}=$ number of trees per hectare before harvest

a In the case of harvesting of LT together with SL (supply system B), the time consumption per tree was reduced by $18 \%$ compared to system A, according to Danielsson and Liss (2010). ${ }^{\mathrm{b}}$ According to Danielsson and Liss (2010), the felling time consumption in the integrated harvesting of SPC, SL and LT is $53 \%$ of the total work-time per tree, while the remaining share of work-time per tree (47\%) was allocated to the harvester used for processing SPC, SL and LT. ${ }^{c}$ According to the simulation presented by Berg et al. (2014), the time for extracting the SPC is $8.4 \mathrm{~s} /$ tree, this extra time was added to the feller-puller work-time per tree. 
Table 7. Forwarder time consumption models, with $\mathrm{PMOh/t}$ as the response variable and forwarding distance (dist; $\mathrm{m}$ ) as the independent variable. Model: $\mathrm{Y}=\mathrm{a}+\mathrm{b} \times$ dist.

\begin{tabular}{|c|c|c|c|c|c|c|c|}
\hline $\begin{array}{l}\text { Supply } \\
\text { system } \\
\text { option }\end{array}$ & $\begin{array}{l}\text { Extraction } \\
\text { phase }\end{array}$ & Assortment & $a$ & $\mathrm{~b}$ & $\begin{array}{c}\text { Load } \\
\text { size }(\mathrm{t})^{*}\end{array}$ & Eq. & $\begin{array}{c}\text { Time } \\
\text { consumption } \\
\text { Ref. }\end{array}$ \\
\hline $\bar{A}$ & FT & PL & 0.16017 & 0.00014 & 4.4 & 12 & $\begin{array}{c}\text { Brunberg } \\
(2004)\end{array}$ \\
\hline A & ST & SL & 0.13674 & 0.00010 & 6.0 & 13 & $\begin{array}{c}\text { Brunberg } \\
(2004)\end{array}$ \\
\hline A & ST & PL & 0.13668 & 0.00010 & 5.7 & 14 & $\begin{array}{c}\text { Brunberg } \\
(2004)\end{array}$ \\
\hline A & $\mathrm{FF}$ & SL & 0.07255 & 0.00008 & 6.5 & 15 & $\begin{array}{c}\text { Brunberg } \\
(2004)\end{array}$ \\
\hline A & $\mathrm{FF}$ & PL & 0.09430 & 0.00008 & 6.1 & 16 & $\begin{array}{c}\text { Brunberg } \\
(2004)\end{array}$ \\
\hline A & FF & LR & 0.11509 & 0.00015 & 4.0 & 17 & Nurmi (2007) \\
\hline A & FF & SP & 0.27119 & 0.00013 & 5.9 & 18 & $\begin{array}{l}\text { Laitila et al. } \\
\quad(2008)\end{array}$ \\
\hline B & $\mathrm{FT}$ & RS & 0.14021 & 0.00026 & 3.5 & 19 & $\begin{array}{l}\text { Laitila et al. } \\
\quad(2007)\end{array}$ \\
\hline B & ST & LT & 0.14504 & 0.00009 & 6.1 & 20 & $\begin{array}{l}\text { Danielsson } \\
\text { and Liss } \\
(2010)\end{array}$ \\
\hline B & FF & $\mathrm{SL}+\mathrm{SPC}$ & 0.06975 & 0.00008 & 6.5 & 21 & $\begin{array}{c}\text { Brunberg } \\
(2004)\end{array}$ \\
\hline B & $\mathrm{FF}$ & LT & 0.07084 & 0.00008 & 6.8 & 22 & $\begin{array}{l}\text { Danielsson } \\
\text { and Liss } \\
(2010)\end{array}$ \\
\hline C & ET & WT & 0.12134 & 0.00026 & 3.4 & 23 & $\begin{array}{l}\text { Laitila et al. } \\
\quad(2007)\end{array}$ \\
\hline C & ET & BWT & 0.07574 & 0.00016 & 4.2 & 24 & $\begin{array}{l}\text { Laitila et al. } \\
\text { (2009) }\end{array}$ \\
\hline C & FT & $\mathrm{RS}$ & 0.14374 & 0.00027 & 3.5 & 25 & $\begin{array}{l}\text { Laitila et al. } \\
\quad(2007)\end{array}$ \\
\hline
\end{tabular}

*Fresh tonnes obtained by multiplying ODt by 2. 
Table 8. Trucking terminal times (sum of loading, unloading and complementary times), load capacities and driving time $\left(\mathrm{PM}_{15} \mathrm{~h} / \mathrm{km} / \mathrm{t}\right)$ as the response variables and trucking distance (dist; $\left.\mathrm{km}\right)$ as the independent variable. Model: $\mathrm{Y}=\mathrm{a} \times$ dist. $^{\mathrm{b}}$

\begin{tabular}{|c|c|c|c|c|c|c|}
\hline Assortment & $\begin{array}{l}\text { Terminal time } \\
\left(\mathrm{PM}_{15} \mathrm{~h} / \mathrm{load}\right)\end{array}$ & $\begin{array}{c}\text { Truck } \\
\text { capacity } \\
(\mathrm{t})\end{array}$ & $\mathrm{a}$ & b & Eq. & Terminal time Ref. \\
\hline SL, SPC & 1.061 & 19.60 & 0.0052 & -0.2783 & 26 & $\begin{array}{l}\text { Nurminen and Heinonen } \\
\text { (2007) }\end{array}$ \\
\hline PL & 1.034 & 18.80 & 0.0054 & -0.2783 & 27 & $\begin{array}{l}\text { Nurminen and Heinonen } \\
\qquad(2007)\end{array}$ \\
\hline BWT & 1.132 & 18.06 & 0.0056 & -0.2783 & 28 & Laitila et al. (2009) \\
\hline W'T & 0.995 & 12.60 & 0.0081 & -0.2783 & 29 & Laitila and Väätäinen (2012) \\
\hline RS & 0.996 & 13.53 & 0.0075 & -0.2783 & 30 & Laitila and Väätäinen (2012) \\
\hline LT & 0.998 & 13.53 & 0.0075 & -0.2783 & 31 & Laitila and Väätäinen (2012) \\
\hline SP & 1.421 & 11.35 & 0.0090 & -0.2783 & 32 & Lindberg (2008) \\
\hline 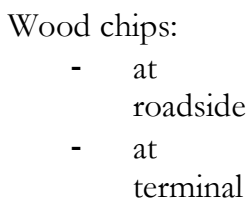 & 1.384 & $\begin{array}{l}16.20 \\
16.50\end{array}$ & 0.0063 & -0.2783 & 33 & Liss and Johansson (2006) \\
\hline $\begin{aligned} S P_{\text {pre-crushed }} & \\
- & \text { at } \\
& \text { roadside } \\
- & \text { at } \\
& \text { terminal }\end{aligned}$ & 1.531 & $\begin{array}{l}15.64 \\
16.00\end{array}$ & 0.0065 & -0.2783 & 34 & $\begin{array}{l}\text { Von Hofsten and Granlund } \\
\qquad(2010)\end{array}$ \\
\hline
\end{tabular}


Table 9. Hourly cost calculation for the forest machinery included in the analyses.

\begin{tabular}{|c|c|c|c|c|c|c|c|c|c|c|c|c|c|}
\hline Description & $\begin{array}{l}\text { Cleaning } \\
\text { saw }\end{array}$ & $\begin{array}{l}\text { Thinning } \\
\text { harvester }\end{array}$ & $\begin{array}{l}\text { Medium } \\
\text { harvester }\end{array}$ & $\begin{array}{l}\text { Large } \\
\text { harvester }\end{array}$ & $\begin{array}{l}\text { Small } \\
\text { Forwarder }\end{array}$ & $\begin{array}{l}\text { Medium } \\
\text { Forwarder }\end{array}$ & $\begin{array}{l}\text { Large } \\
\text { Forwarder }\end{array}$ & $\begin{array}{l}\text { Excavator } \\
\text { for stump } \\
\text { lifting }\end{array}$ & Chipper & Shredder & $\begin{array}{l}\text { Grapple } \\
\text { loader }\end{array}$ & $\begin{array}{l}\text { Thinning } \\
\text { harvester } \\
\text { for boom } \\
\text { corridor }\end{array}$ & $\begin{array}{l}\text { Small } \\
\text { Forwarder } \\
\text { with } \\
\text { compacting } \\
\text { stakes }\end{array}$ \\
\hline Purchase price $(€)$ & $924^{a}$ & $442935^{\mathrm{b}}$ & $456522^{\mathrm{b}}$ & $494565^{\mathrm{b}}$ & $285326^{\mathrm{b}}$ & $315217^{\mathrm{b}}$ & $347826^{\mathrm{b}}$ & $155435^{c}$ & $510870^{d}$ & $326087^{e}$ & $163043^{c}$ & 575815 & 299592 \\
\hline Economic Lifespan (Years) & 2 & 4.8 & 4.8 & 4.8 & 4.8 & 4.8 & 4.8 & 6 & 6 & 6 & 6 & 4.8 & 4.8 \\
\hline Interest rate $(\%)$ & 6 & 6 & 6 & 6 & 6 & 6 & 6 & 6 & 6 & 6 & 6 & 6 & 6 \\
\hline Salvage present value $(€)$ & 0 & 66973 & 69028 & 74780 & 43142 & 47662 & 52593 & 21915 & 72029 & 45976 & 22988 & 87065 & 45299 \\
\hline Depreciation ( $€ /$ year $)$ & 504 & 92456 & 95292 & 103233 & 59558 & 65797 & 72604 & 27153 & 89244 & 56964 & 28482 & 120193 & 62536 \\
\hline General maintenance cost $(€ / \text { year })^{\mathrm{f}}$ & 18 & 8859 & 9130 & 9891 & 5707 & 6304 & 6957 & 3109 & 6522 & 6522 & 3261 & 11516 & 5992 \\
\hline Operating hours $\left(\mathrm{PM}_{15} \mathrm{~h} /\right.$ year $)$ & 1000 & 2500 & 2500 & 2500 & 2500 & 2500 & 2500 & 1500 & 1500 & 1500 & 1500 & 2500 & 2500 \\
\hline Fixed cost (€/PM15h) & 0.54 & 40.54 & 41.74 & 45.22 & 26.09 & 28.80 & 31.85 & 20.22 & 63.80 & 42.28 & 21.20 & 52.72 & 27.39 \\
\hline Fixed cost $\left(€ / \mathrm{PM}_{15} \mathrm{~h}\right)^{*}$ & 0.54 & 42.50 & 43.80 & 47.50 & 27.39 & 30.33 & 33.37 & 21.20 & 67.07 & 44.46 & 22.17 & 55.33 & 28.80 \\
\hline Variable maintenance cost $\left(€ / \mathrm{PM}_{15} \mathrm{~h}\right)^{\mathrm{f}}$ & 0.40 & 12.93 & 13.37 & 14.46 & 7.17 & 7.93 & 8.70 & 9.02 & 21.74 & 21.74 & 7.61 & 16.85 & 7.50 \\
\hline Fuel and lubricant cost $\left(€ / \mathrm{PM}_{15} \mathrm{~h}\right)$ & 2.72 & 20.33 & 22.72 & 25.22 & 16.09 & 16.96 & 19.46 & 23.15 & 67.07 & 48.70 & 16.41 & 20.33 & 16.09 \\
\hline Labor cost $\left(€ / \mathrm{PM}_{15} \mathrm{~h}\right)$ & 27.17 & 27.17 & 27.17 & 27.17 & 27.17 & 27.17 & 27.17 & 27.17 & 27.17 & 27.17 & 27.17 & 27.17 & 27.17 \\
\hline Variable cost $\left(€ / \mathrm{PM}_{15} \mathrm{~h}\right)$ & 30.22 & 60.43 & 63.26 & 66.74 & 50.43 & 51.96 & 55.33 & 59.35 & 115.98 & 97.61 & 51.20 & 64.35 & 50.76 \\
\hline Variable cost $\left(€ / \mathrm{PM}_{15} \mathrm{~h}\right)^{*}$ & 31.74 & 63.48 & 66.41 & 70.11 & 52.93 & 54.57 & 58.04 & 62.28 & 121.85 & 102.39 & 53.70 & 67.50 & 53.26 \\
\hline Total cost $\left(€ / \mathrm{PM}_{15} \mathrm{~h}\right)^{*}$ & 32.28 & 105.98 & 110.22 & 117.61 & 80.33 & 84.89 & 91.52 & 83.48 & 188.80 & 146.85 & 75.98 & 122.83 & 82.07 \\
\hline
\end{tabular}

a,b,c,d,e = Reference for purchase price: (a) Stibl GmbH (mmm.stihl.se), (b) John Deere forestry Oy (pers. comm.), (c) Volvo AB (pers comm.), (d) Bruks AB (pers. comm.), (e) Doppstadt GmbH (OP System AB, pers. comm.).

$\mathrm{f}=$ Information on fixed costs and repair and maintenance costs for the harvesters and the forwarders were obtained from Nurminen et al. (2009); for the chipper from Karlsson (2010), for shredders from OP System AB; for cleaning saws and grapple loaders from professional operators; and for the excavators from Kärhä (2012).

$=$ Including a $5 \%$ profit 
Table 10. Costs elements included in the road transportation cost calculations.

\begin{tabular}{|c|c|c|c|c|c|c|c|}
\hline $\begin{array}{c}\text { Cost } \\
\text { element }\end{array}$ & $\begin{array}{l}\text { Timber truck } \\
\text { and trailer } \\
\text { SL, PL, SPC }\end{array}$ & $\begin{array}{c}\text { Timber truck } \\
\text { and trailer } \\
\text { BWT }\end{array}$ & $\begin{array}{l}\text { Logging } \\
\text { residues truck } \\
\text { and trailer } \\
\text { WS, RS }\end{array}$ & $\begin{array}{l}\text { Logging } \\
\text { residues } \\
\text { truck and } \\
\text { trailer } \\
\text { LT }\end{array}$ & $\begin{array}{l}\text { Logging } \\
\text { residues } \\
\text { truck and } \\
\text { trailer } \\
\text { SP }\end{array}$ & $\begin{array}{l}\text { Woodchips } \\
\text { truck and } \\
\text { trailer } \\
\text { chipped } \\
\text { LR }\end{array}$ & $\begin{array}{l}\text { Woodchips } \\
\text { truck and } \\
\text { trailer } \\
\text { pre- } \\
\text { crushed SP }\end{array}$ \\
\hline $\begin{array}{l}\text { Purchase } \\
\text { price }(€)\end{array}$ & 282609 & 282609 & 380435 & 380435 & 380435 & 358696 & 358696 \\
\hline $\begin{array}{l}\mathrm{Fh}^{*} \\
\left(€ / \mathrm{PM}_{15} \mathrm{~h}\right)\end{array}$ & 36.74 & 36.74 & 37.61 & 37.61 & 37.61 & 37.39 & 37.39 \\
\hline $\begin{array}{l}\text { Vkm* } \\
(€ / \mathrm{km})\end{array}$ & 1.05 & 1.05 & 1.20 & 1.20 & 1.20 & 1.12 & 1.12 \\
\hline $\begin{array}{l}\text { Vld } \\
(€ / / \text { oad })\end{array}$ & 19.35 & 19.02 & 19.89 & 21.96 & 25.54 & 25.00 & 29.78 \\
\hline
\end{tabular}

*Annual utilization of $3700 \mathrm{PM}_{15} \mathrm{~h}$ was considered for all trucks. The lifetime was set to $1000000 \mathrm{~km}$ for the truck, $1500000 \mathrm{~km}$ for the trailer and 5000 loads for the crane. The salvage value was assumed to be $10 \%$ of the initial investment for the truck and $7 \%$ for the trailer and the crane. The fuel consumption for terminal and driving activities were set respectively to $7.7 \mathrm{l} / \mathrm{PM}_{15} \mathrm{~h}$ and $0.56 \mathrm{l} / \mathrm{km}$. 
Table 11. Assumed time consumption and costs of terminal operations.

\begin{tabular}{|c|c|c|c|c|c|c|c|}
\hline Operation & Assortment & $\begin{array}{l}\text { Time } \\
\text { consumption } \\
\left(\mathrm{PM}_{15} \mathrm{~h} / \mathrm{t}\right)\end{array}$ & $\begin{array}{l}\text { Hourly cost } \\
\left(€ / \mathrm{PM}_{15} \mathrm{~h}\right)\end{array}$ & $\begin{array}{l}\text { Cost } \\
(€ / t)\end{array}$ & $\begin{array}{l}\text { Ref. time } \\
\text { consumption }\end{array}$ & Ref. Hourly cost & Ref. Cost/t \\
\hline Storage & All & - & - & 2.48 & - & - & $\begin{array}{l}\text { Södeström } \\
(2006)\end{array}$ \\
\hline Debarking & PL & - & - & 3.58 & - & - & $\begin{array}{l}\text { Watson et } \\
\text { al. (1993) }\end{array}$ \\
\hline $\begin{array}{l}\text { Delimbing \& } \\
\text { debarking }\end{array}$ & RS, LT & - & - & 6.88 & - & - & $\begin{array}{l}\text { Watson et } \\
\text { al. (1993) }\end{array}$ \\
\hline Chipping & PL, BWT & 0.016 & 391.30 & 6.42 & $\begin{array}{l}\text { Eliasson \& } \\
\text { Granlund } \\
(2010)\end{array}$ & Karlsson (2010) & - \\
\hline Grinding & LR & 0.023 & 380.43 & 8.84 & $\begin{array}{l}\text { Eliasson \& } \\
\text { Granlund } \\
(2010)\end{array}$ & Karlsson (2010) & - \\
\hline Chipping & $\begin{array}{l}\text { RS, LT, } \\
\text { WT }\end{array}$ & 0.021 & 391.30 & 8.41 & $\begin{array}{l}\text { Eliasson et al. } \\
\text { (2012) }\end{array}$ & Karlsson (2010) & - \\
\hline Pre-crushing & SP & 0.034 & 380.43 & 12.91 & $\begin{array}{l}\text { Eliasson \& } \\
\text { Granlund } \\
(2010)\end{array}$ & Karlsson (2010) & - \\
\hline Re-fining & $\begin{array}{l}\text { SP pre- } \\
\text { crushed }\end{array}$ & 0.025 & 380.43 & 9.33 & $\begin{array}{l}\text { Von Hofsten \& } \\
\text { Granlund } \\
(2010)\end{array}$ & Karlsson (2010) & - \\
\hline Sieving & SPC & 0.200 & 17.39 & 3.45 & $-a$ & $\begin{array}{l}\text { DIMEC Srl. } \\
\text { Pers. comm. }\end{array}$ & - \\
\hline Grinding & SPC & 0.025 & 380.43 & 9.33 & $\begin{array}{l}\text { Von Hofsten } \\
\text { and Granlund } \\
(2010)\end{array}$ & Karlsson (2010) & - \\
\hline
\end{tabular}




\begin{tabular}{|c|c|c|c|c|c|c|}
\hline Re-loading & PL & 0.016 & 81.52 & 1.32 & $-b$ & cf. Table 10 \\
\hline Re-loading & woodchips & 0.030 & 81.52 & 2.30 & $\begin{array}{l}\text { Laitila and } \\
\text { Väätäinen } \\
2012\end{array}$ & cf. Table 10 \\
\hline Re-loading & $\begin{array}{l}\text { SP pre- } \\
\text { crushed }\end{array}$ & 0.031 & 81.52 & 2.38 & $\begin{array}{l}\text { Laitila and } \\
\text { Väätäinen } \\
2012^{c}\end{array}$ & cf. Table 10 \\
\hline $\begin{array}{l}\text { Transportation } \\
5 \mathrm{~km} \operatorname{logs}\end{array}$ & PL & 0.020 & 65.50 & 1.28 & $-d$ & cf. Table 11 \\
\hline $\begin{array}{l}\text { Transportation } \\
5 \mathrm{~km}\end{array}$ & $\begin{array}{l}\text { wood } \\
\text { chips }\end{array}$ & 0.022 & 64.20 & 1.43 & $-d$ & $-e$ \\
\hline $\begin{array}{l}\text { Transportation } \\
5 \mathrm{~km}\end{array}$ & $\begin{array}{l}\text { SP pre- } \\
\text { crushed }\end{array}$ & 0.023 & 64.20 & 1.47 & $-d$ & $-\mathrm{e}$ \\
\hline
\end{tabular}

$\mathrm{a}=$ estimated from measurements carried out using similar machinery by the Authors; $\mathrm{b}=$ measured in a terminal by the authors for similar operations; $\mathrm{c}=\mathrm{based}$ on Laitila and Väätäinen 2012 and the density of pre-crushed stumps assumed according to Von Hofsten and Granlund (2010); $\mathrm{d}=\mathrm{calculated}$ for a transportation distance of $5 \mathrm{~km}$; $e=$ the costs of $36.63 € / \mathrm{PM}_{15} \mathrm{~h}$ and $1.01 € / \mathrm{Km}$ were used for a container truck. 
Table 12. Fuel and lubricant consumption of forest machinery.

\begin{tabular}{|c|c|c|c|c|c|}
\hline Machinery & $\begin{array}{l}\text { Engine } \\
\text { power } \\
(\mathrm{kW})\end{array}$ & $\begin{array}{l}\text { Fuel } \\
\text { consumption } \\
\left(L_{\text {diesel }} / \mathrm{h}\right)\end{array}$ & Reference & $\begin{array}{l}\text { Lubricant consumption } \\
\text { (\% of fuel consumption } \\
\text { or } \mathrm{l} / \mathrm{h} \text { for shredder and } \\
\text { chipper) }\end{array}$ & Reference \\
\hline Cleaning saw & 2.2 & $0.75^{*}$ & (Stihl GmbH www.stihl.se.) & & \\
\hline \multirow[t]{3}{*}{ Harvester } & 150 & 14.0 & (Brunberg 2006) & 6.0 & (Berg \& Lindholm 2005) \\
\hline & 170 & 15.7 & (Brunberg 2006) & 6.0 & (Berg \& Lindholm 2005) \\
\hline & 190 & 17.4 & (Brunberg 2006) & 6.0 & (Berg \& Lindholm 2005) \\
\hline Fixteri baler-harvester & 150 & 16.0 & (Jylhä 2011) & 6.0 & (Berg \& Lindholm 2005) \\
\hline \multirow[t]{3}{*}{ Forwarder } & 140 & 11.8 & (Brunberg 2006) & 3.0 & (Nurminen et al. 2009) \\
\hline & 150 & 12.4 & (Brunberg 2006) & 3.0 & (Nurminen et al. 2009) \\
\hline & 180 & 14.2 & (Brunberg 2006) & 3.0 & (Nurminen et al. 2009) \\
\hline Excavator & 130 & 16.0 & (Von Hofsten, H. 2011) & 6.0 & (Berg \& Lindholm 2005) \\
\hline Shredder & 328 & 36.8 & (Skogforsk 2010) & 0.45 & $\begin{array}{l}\text { (“OP System AB" Pers. } \\
\text { Comm.) }\end{array}$ \\
\hline Grapple loader & 120 & 12.0 & $\begin{array}{l}\text { (“Domsjo Fiber AB" Pers. } \\
\text { Comm.) }\end{array}$ & 3.0 & (Nurminen et al. 2009) \\
\hline Chipper & 331 & 51.1 & (Karlsson 2010) & 0.45 & $\begin{array}{l}\text { “OP System AB" Pers. } \\
\text { Comm.) }\end{array}$ \\
\hline Feller-puller & 220 & 20.0 & (Brunberg 2006) & 6.0 & (Berg \& Lindholm 2005) \\
\hline
\end{tabular}


Table 13. Fuel and lubricant consumption of terminal machinery.

\begin{tabular}{|c|c|c|c|c|c|}
\hline Machinery & $\begin{array}{l}\text { Engine } \\
\text { power } \\
(\mathrm{kW})\end{array}$ & $\begin{array}{l}\text { Fuel } \\
\text { consumption } \\
\left(L_{\text {diese }} / t\right)\end{array}$ & Reference & $\begin{array}{l}\text { Lubricant } \\
\text { consumption } \\
\text { ( } / / h \text { or \% of } \\
\text { fuel } \\
\text { consumption } \\
\text { for loaders) }\end{array}$ & Reference \\
\hline Large disc chipper for WT. RS. LT & 930 & 2.8 & (Eliasson et al. 2012) & 0.45 & (“OP System AB" Pers. Comm.) \\
\hline Large disc chipper for BWT and PL & 930 & 1.8 & (Eliasson et al. 2012) & 0.45 & (“OP System $A B$ " Pers. Comm.) \\
\hline $\begin{array}{l}\text { Large grinder for residues (energy } \\
\text { fraction) }\end{array}$ & 780 & 2.0 & $\begin{array}{l}\text { Eliasson \& Granlund P. } \\
\text { 2010) }\end{array}$ & 0.45 & (“OP System $A B$ " Pers. Comm.) \\
\hline Large grinder to refine SP & 780 & 1.4 & $\begin{array}{l}\text { (Von Hofsten \& Granlund } \\
\text { 2010)) }\end{array}$ & 0.45 & (“OP System $A B$ " Pers. Comm.) \\
\hline Large grinder to crush whole SP & 780 & 2.6 & $\begin{array}{l}\text { (Eliasson L. \& Granlund } \\
\text { P. 2010) }\end{array}$ & 0.45 & (“OP System $A B$ " Pers. Comm.) \\
\hline Loader for chips and pre-crushed SP & 120 & 0.4 & $\begin{array}{l}\text { (“Domsjö Fiber AB" Pers. } \\
\text { Comm.) }\end{array}$ & 3.00 & (Nurminen et al. 2009) \\
\hline Front lift loader for wood & 120 & 0.2 & $\begin{array}{l}\text { (“Domsjö Fiber AB" Pers. } \\
\text { Comm.) ) }\end{array}$ & 3.00 & (Nurminen et al. 2009) \\
\hline $\begin{array}{l}\text { Chain flail delimber/debarker for RS and } \\
\text { LT }\end{array}$ & 180 & 1.9 & (Kons \& Läspä 2013) & 0.45 & (“OP System $A B$ " Pers. Comm.) \\
\hline $\begin{array}{l}\text { Chain flail delimber/debarker only in } \\
\text { debarking PL (bark fraction: same fuel } \\
\text { consumption) }\end{array}$ & 180 & 1.3 & (Kons \& Läspä 2013) & 0.45 & (“OP System $A B$ " Pers. Comm.) \\
\hline Saw-blade & 11 & $0.2^{*}$ & $\begin{array}{l}\text { (“DIMEC srl”. Pers. } \\
\text { Comm.) }\end{array}$ & & \\
\hline
\end{tabular}


Table 14. Potential production (1000 t) in total for the $120 \mathrm{~km}$ radius supply area of the ORN location. Sawlogs are delivered with bark, pulpwood as debarked logs and the other assortments are chipped.

\begin{tabular}{|c|c|c|c|c|c|c|c|c|c|}
\hline $\begin{array}{l}\text { Supply } \\
\text { system }\end{array}$ & Harvest operation & & Sawlogs & Pulpwood & PL bark & $\begin{array}{l}\text { tops and } \\
\text { branches }\end{array}$ & Stump-wood & small trees & Total \\
\hline \multirow[t]{6}{*}{ A } & $\mathrm{FT}$ & & 5 & 39 & 4 & thong & 0 & 0 & 43 \\
\hline & ST & & 111 & 223 & 15 & 0 & 0 & 0 & 349 \\
\hline & FF & Roundwood harvest & 835 & 328 & 31 & 0 & 0 & 0 & 1194 \\
\hline & & Residue recovery & 0 & 0 & 0 & 273 & 0 & 0 & 273 \\
\hline & & Stump extraction & 0 & 0 & 0 & 0 & 479 & 0 & 479 \\
\hline & Total & & 946 & 590 & 50 & 273 & 479 & 0 & 2338 \\
\hline \multirow[t]{6}{*}{ B } & FT & & 0 & 39 & 4 & 12 & 0 & 0 & 54 \\
\hline & ST & & 111 & 223 & 15 & 115 & 0 & 0 & 464 \\
\hline & FF & Without SPC harvest & 835 & 328 & 31 & 215 & 0 & 0 & 1408 \\
\hline & or 1 & With SPC harvest & 835 & 328 & 31 & 215 & 100 & 0 & 1509 \\
\hline & Total, with SPC harvest & & 946 & 590 & 50 & 341 & 100 & 0 & 2027 \\
\hline & Total, with conventional SP & extraction & 946 & 590 & 50 & 341 & 479 & 0 & 2406 \\
\hline \multirow[t]{3}{*}{ C } & Same as B, plus & Energy thinning & 0 & 0 & 0 & 0 & 0 & 84 & 84 \\
\hline & Total, with SPC harvest & & 946 & 590 & 50 & 341 & 100 & 84 & 2111 \\
\hline & Total, with conventional SP & harvest & 946 & 590 & 50 & 341 & 479 & 84 & 2490 \\
\hline
\end{tabular}


Table 15. Total costs (M EUR) to supply the amounts of feedstock according to Table 14, by harvest type and operation.

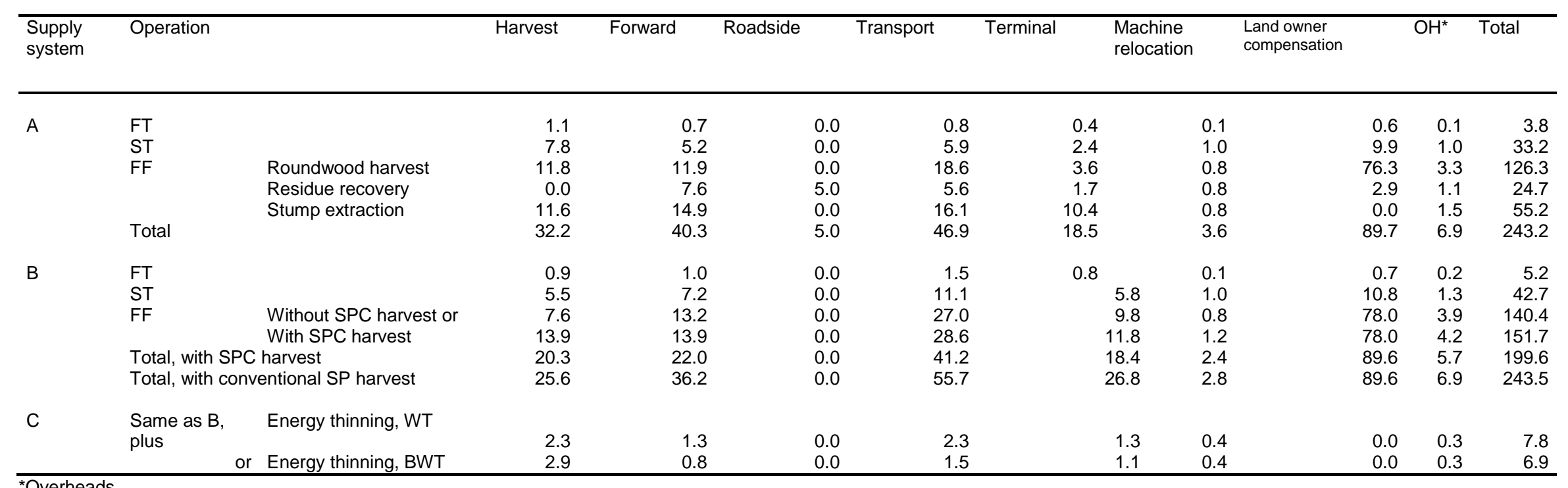

*Overheads 


\section{Figure list}

Figure 1. Map of Sweden with the study area indicated by a circle (on the left) and geographical representation of the three potential "biorefineries" considered (on the right). UME is denoted as A, ORN as $\mathrm{C}$ and $\mathrm{STO}$ as B.

Figure 2. Supply cost and energy use curves for pulpwood logs, arranged by type of harvesting operation. Figure 3. Supply cost and energy use curves for chipped tops and branches.

Figure 4. Supply cost and energy use curves for chipped stump wood.

Figure 5. Supply cost and energy use curves for chipped small trees from energy thinnings.

Figure 6. Aggregated supply cost curves for all assortments combined. All assortments are chipped without sorting.

Figure 7. Aggregated energy use curves corresponding to the ORN cost curves in Figure 6.

Figure 8. Aggregated supply cost curves for all assortments combined under three variations of key input parameters. All assortments are chipped without sorting. 


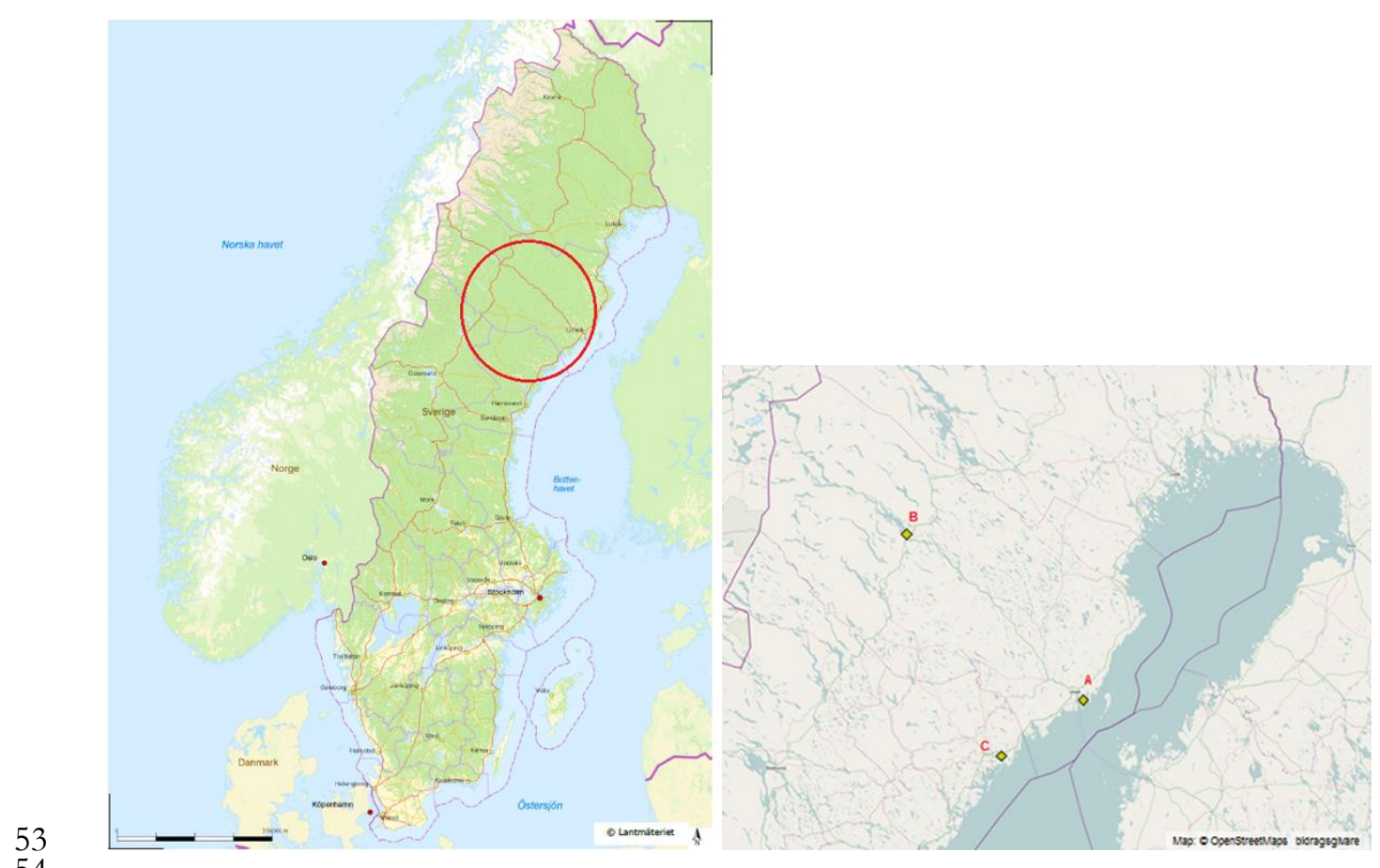

Figure 1 

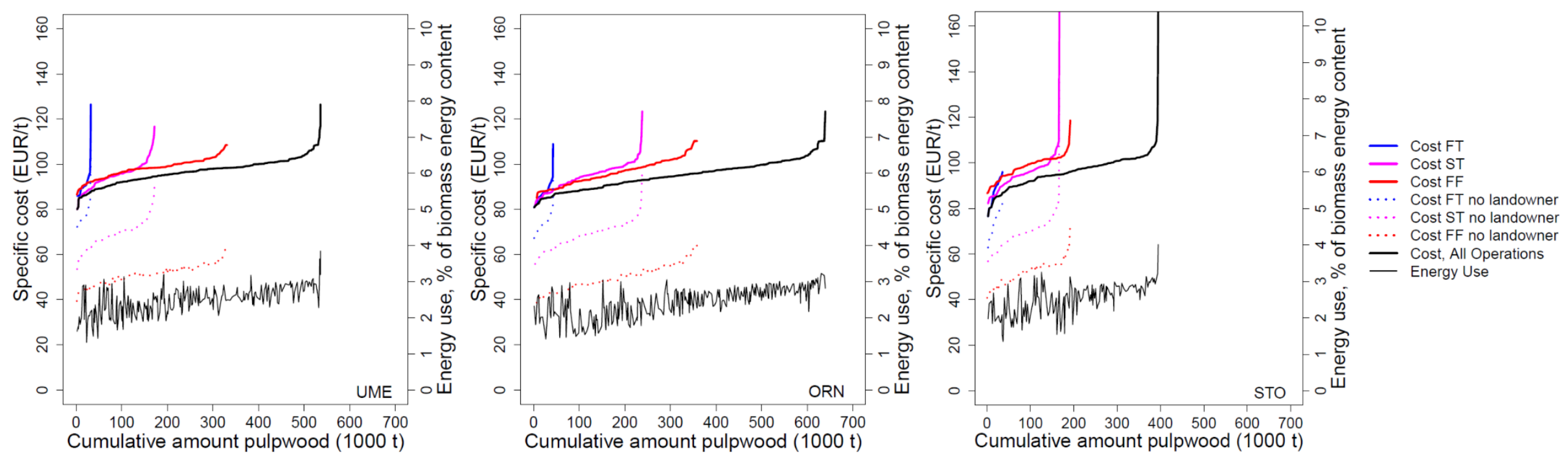

Figure 2 

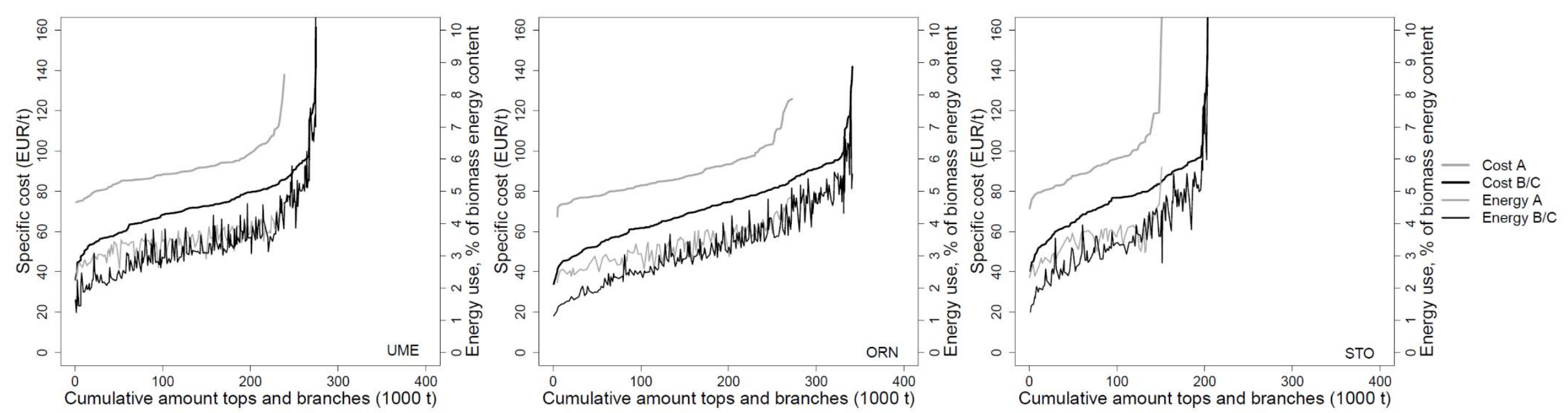

Figure 3 

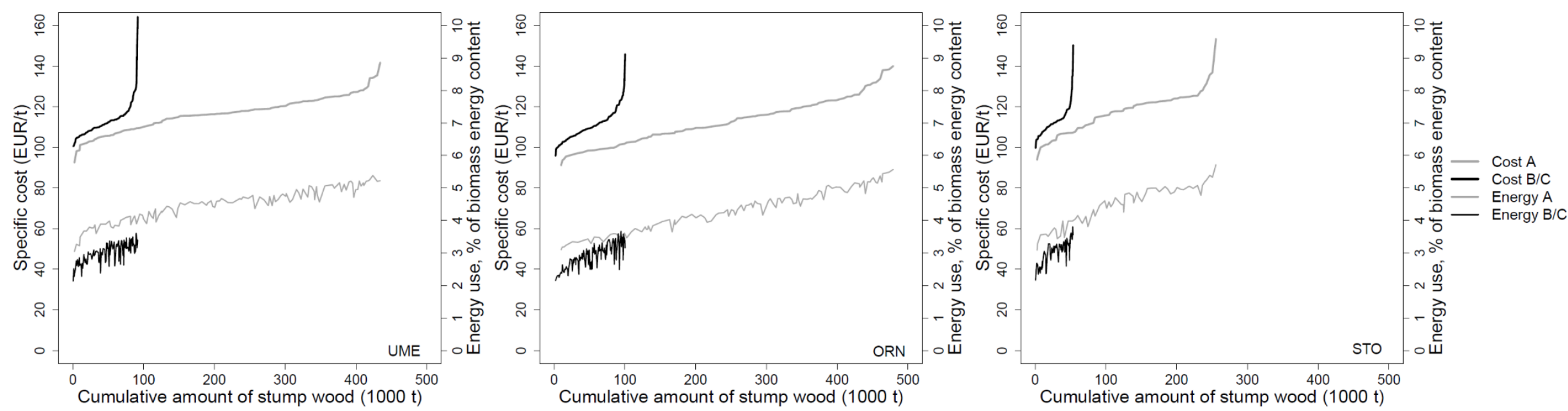

Figure 4 

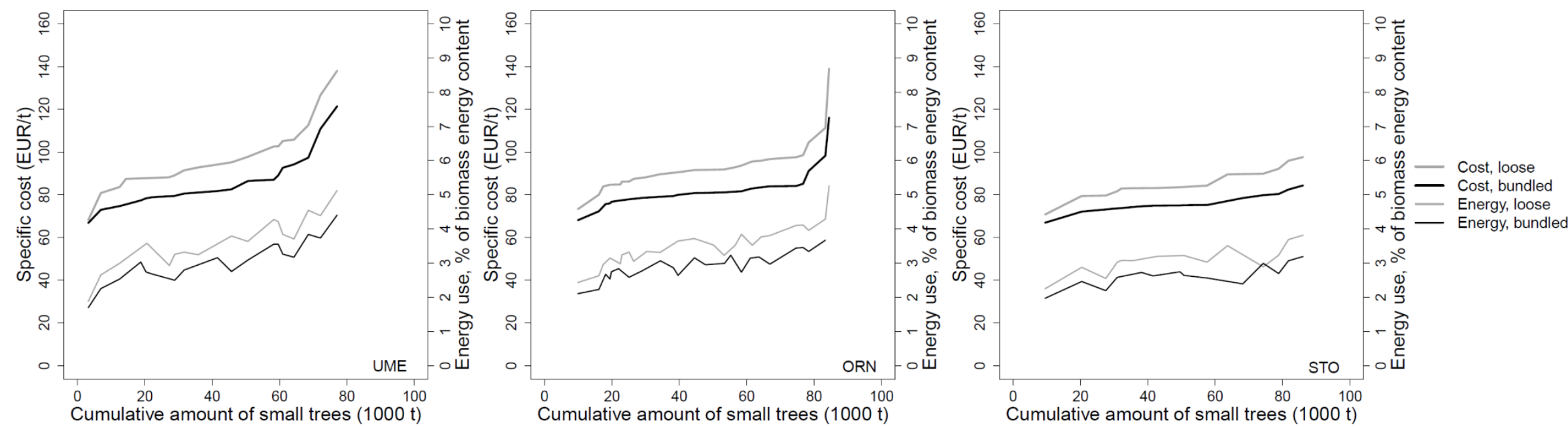

Figure 5 

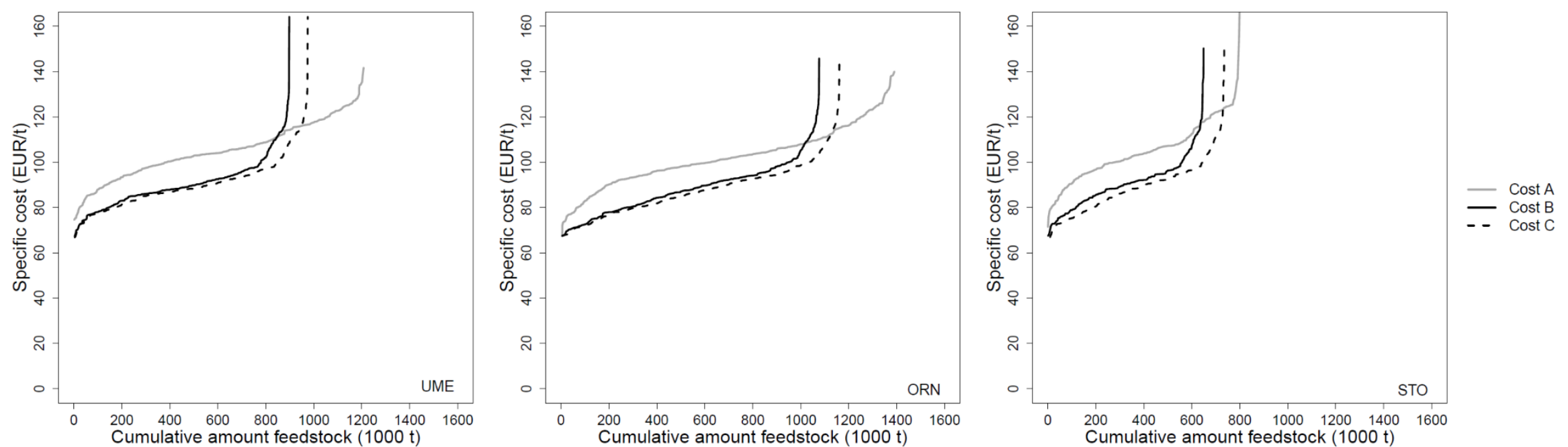

Figure 6 


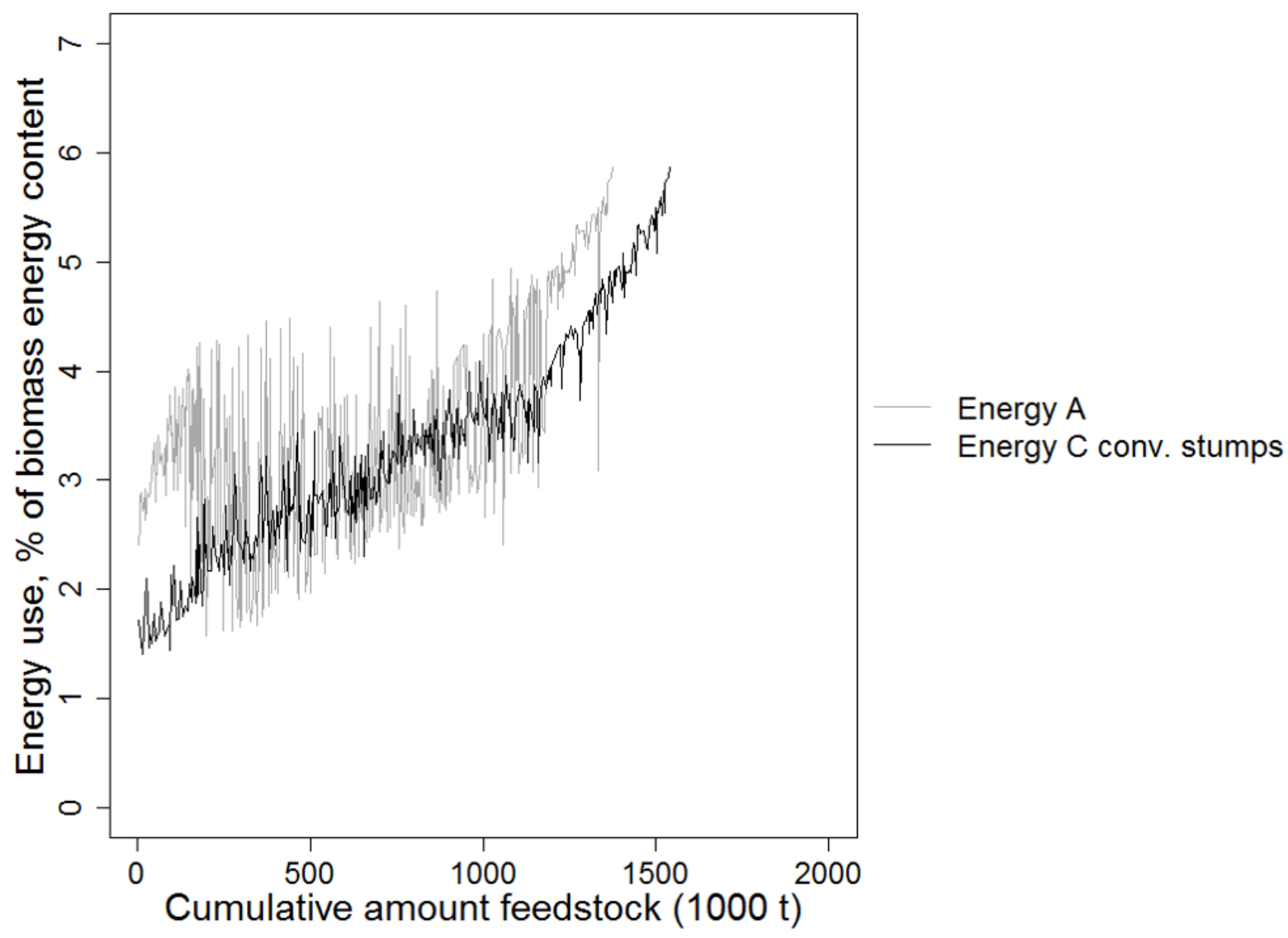

Figure 7 


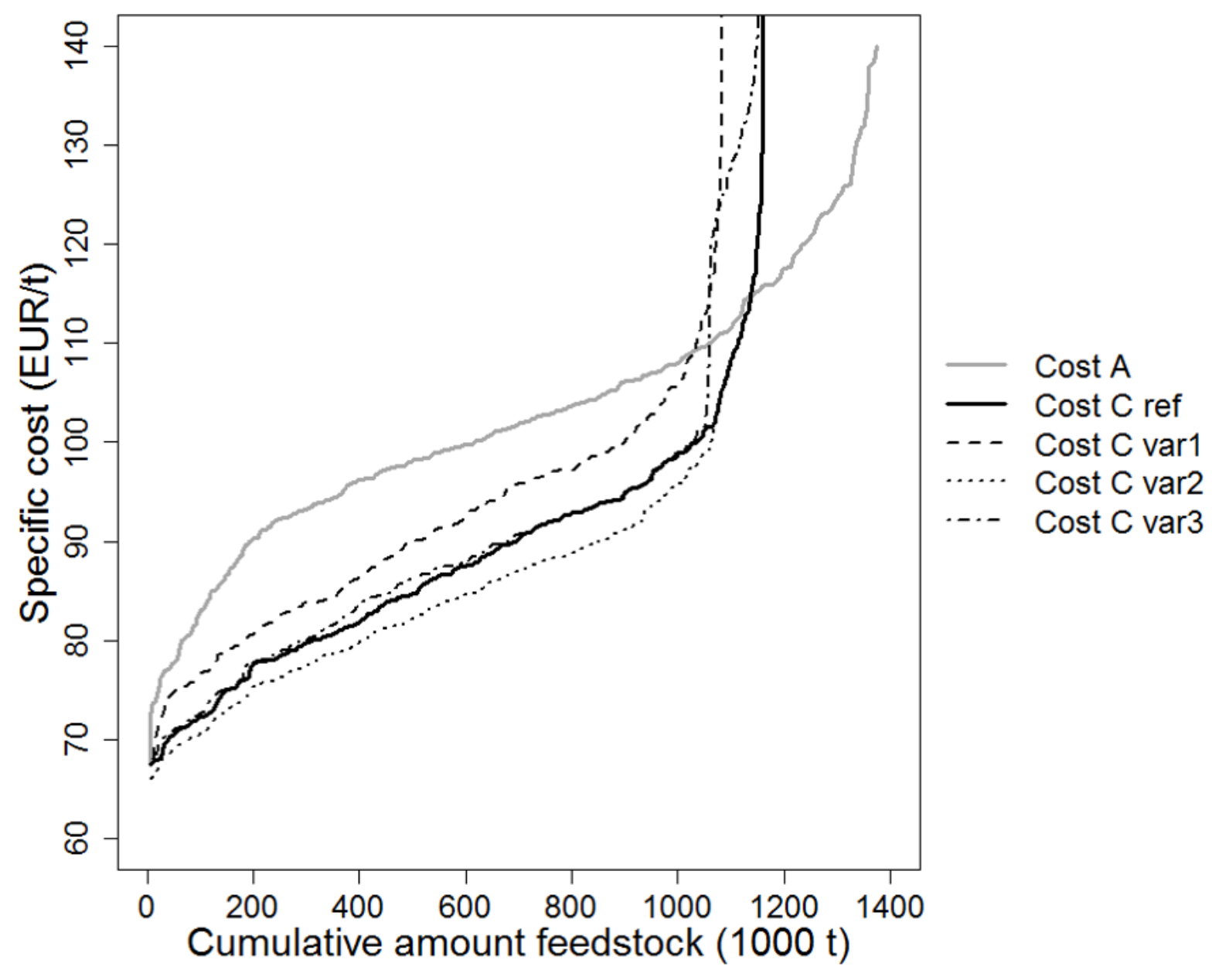

Figure 8 


\begin{tabular}{|c|c|c|c|c|c|c|c|c|}
\hline & $\mathrm{A}$ & & & $\mathrm{B}$ & & & $\mathrm{C}$ & \\
\hline $\begin{array}{l}\text { Treatment } \\
> \\
\text { Product }\end{array}$ & $\begin{array}{l}\text { Fixed } \\
\text { cost } \\
(€ / t)\end{array}$ & $\begin{array}{l}\text { Variable cost } \\
\qquad(€ / t)\end{array}$ & $\begin{array}{c}\text { Treatmen } \\
\mathrm{t} \\
> \\
\text { product }\end{array}$ & $\begin{array}{l}\text { Fixed } \\
\text { cost } \\
(€ / t)\end{array}$ & $\begin{array}{l}\text { Variable cost } \\
\qquad(€ / t)\end{array}$ & $\begin{array}{l}\text { Treatment } \\
> \\
\text { product }\end{array}$ & $\begin{array}{l}\text { Fixed } \\
\operatorname{cost} \\
(€ / t)\end{array}$ & $\begin{array}{l}\text { Variable cost } \\
\qquad(€ / t)\end{array}$ \\
\hline \multirow{7}{*}{$\begin{array}{l}\text { PCT } \\
> \\
\text { WT left in } \\
\text { forest }\end{array}$} & Cleaning saw & Cleaning saw & PCT & Cleaning saw & Cleaning saw & ET & Thinning harvester & Thinning harvester \\
\hline & $=0.55 \times 0.38$ & $=31.78 \times 0.38$ & $>$ & $=0.55 \times 0.38$ & $=31.78 \times 0.38$ & $>$ & boom corridor & boom corridor \\
\hline & & & $\begin{array}{l}\text { WT left } \\
\text { in stand }\end{array}$ & & & WT & $=55.32 \times 0.20$ & $=67.52 \times 0.20$ \\
\hline & & & & & & & $\begin{array}{l}\text { Small forwarder comp. } \\
=0.0076 \times \mathrm{fd}(\mathrm{m})+3.50\end{array}$ & $\begin{array}{l}\text { Small forwarder comp. } \\
=0.014 \times \mathrm{fd}(\mathrm{m})+6.50\end{array}$ \\
\hline & & & & & & & $\begin{array}{l}\text { Logging residues truck } \\
\text { and trailer } \\
=37.61 \times[0.079+(0.008 \\
\left.\times \operatorname{td}(\mathrm{km})^{-0.278}\right) \times \\
\operatorname{td}(\mathrm{km})]\end{array}$ & $\begin{array}{l}\text { Logging residues truck and } \\
\text { trailer } \\
=[(1.20 \times 2 \times \operatorname{td}(\mathrm{km})) / 12.6] \\
+(19.89 / 12.6)\end{array}$ \\
\hline & & & & & & $\begin{array}{l}\text { ET } \\
> \\
\text { BWT }\end{array}$ & $\begin{array}{l}\text { Bundle harvester } \\
=62.45 \times 0.20\end{array}$ & $\begin{array}{l}\text { Bundle harvester } \\
=93.68 \times 0.20\end{array}$ \\
\hline & & & & & & & $\begin{array}{l}\text { Small forwarder } \\
=0.0045 \times \mathrm{fd}(\mathrm{m})+2.07\end{array}$ & $\begin{array}{l}\text { Small forwarder } \\
=0.0087 \times \mathrm{fd}(\mathrm{m})+4.03\end{array}$ \\
\hline \multirow{5}{*}{$\begin{array}{l}\mathrm{FT} \\
> \\
\mathrm{PL}\end{array}$} & & & & & & & $\begin{array}{l}\text { Timber truck and } \\
\text { trailer } \\
=36.74 \times[0.063+(0.006 \\
\left.\times \operatorname{td}(\mathrm{km})^{-0.278}\right) \times \\
\operatorname{td}(\mathrm{km})]\end{array}$ & $\begin{array}{l}\text { Timber truck and trailer } \\
=[(1.05 \times 2 \times \mathrm{td}(\mathrm{km})) / 18.1] \\
+(19.02 / 18.1)\end{array}$ \\
\hline & Thinning harvester & Thinning harvester & \multirow{4}{*}{$\begin{array}{l}\mathrm{FT} \\
> \\
\mathrm{RS}\end{array}$} & Thinning harvester & Thinning harvester & FT & Thinning harvester & Thinning harvester \\
\hline & $=42.55 \times 0.23$ & $=63.45 \times 0.23$ & & $=42.55 \times 0.15$ & $=63.45 \times 0.15$ & $\overrightarrow{\mathrm{RS}}$ & $=42.54 \times 0.17$ & $=63.45 \times 0.17$ \\
\hline & $\begin{array}{l}\text { Small forwarder } \\
=0.0037 \times \mathrm{fd}(\mathrm{m})+4.39\end{array}$ & $\begin{array}{l}\text { Small forwarder } \\
=0.0073 \times \mathrm{fd}(\mathrm{m})+ \\
8.53\end{array}$ & & $\begin{array}{l}\text { Small forwarder } \\
=0.0071 \times f d(m)+3.84\end{array}$ & $\begin{array}{l}\text { Small forwarder } \\
=0.014 \times \mathrm{fd}(\mathrm{m})+ \\
7.47\end{array}$ & & $\begin{array}{l}\text { Small forwarder } \\
=0.0075 \times \mathrm{fd}(\mathrm{m})+3.94\end{array}$ & $\begin{array}{l}\text { Small forwarder } \\
=0.015 \times \mathrm{fd}(\mathrm{m})+ \\
7.66\end{array}$ \\
\hline & $\begin{array}{l}\text { Timber truck and trailer } \\
=36.74 \times[0.055+(0.005 \times \mathrm{t} \\
\left.\left.\mathrm{d}(\mathrm{km})^{-0.278}\right) \times \operatorname{td}(\mathrm{km})\right]\end{array}$ & $\begin{array}{l}\text { Timber truck and trailer } \\
=[(1.05 \times 2 \times \mathrm{td}(\mathrm{km})) / 18.8] \\
+(19.35 / 18.8)\end{array}$ & & $\begin{array}{l}\text { Logging residues truck } \\
\text { and trailer }\end{array}$ & $\begin{array}{l}\text { Logging residues truck } \\
\text { and trailer }\end{array}$ & & $\begin{array}{l}\text { Logging residues truck } \\
\text { and trailer }\end{array}$ & $\begin{array}{l}\text { Logging residues truck and } \\
\text { trailer } \\
=[(1.20 \times 2 \times \operatorname{td}(\mathrm{km})) / 13.5]\end{array}$ \\
\hline
\end{tabular}




\begin{tabular}{|c|c|c|c|c|c|c|c|c|}
\hline & & & & $\begin{array}{l}=37.61 \times[0.074+(0.008 \\
\left.\times \operatorname{td}(\mathrm{km})^{-0.278}\right) \times \\
\operatorname{td}(\mathrm{km})]\end{array}$ & $\begin{array}{l}=[(1.20 \times 2 \times \\
\operatorname{td}(\mathrm{km})) / 13.5] \\
+(19.89 / 13.5)\end{array}$ & & $\begin{array}{l}=37.61 \times[0.074+(0.008 \\
\left.\times \operatorname{td}(\mathrm{km})^{-0.278}\right) \times \\
\operatorname{td}(\mathrm{km})]\end{array}$ & $+(19.89 / 13.5)$ \\
\hline $\begin{array}{l}\mathrm{ST} \\
>\end{array}$ & $\begin{array}{l}\text { Medium harvester } \\
\text { (SW/PL) }\end{array}$ & $\begin{array}{l}\text { Medium harvester } \\
\text { (SL/PL) }\end{array}$ & & $\begin{array}{l}\text { Medium harvester } \\
\text { (SL) }\end{array}$ & $\begin{array}{l}\text { Medium harvester } \\
\text { (SL) }\end{array}$ & & $\begin{array}{l}\text { Medium harvester } \\
\text { (SL) }\end{array}$ & $\begin{array}{l}\text { Medium harvester } \\
\text { (SL) }\end{array}$ \\
\hline \multirow[t]{6}{*}{$\mathrm{SW}+\mathrm{PL}$} & $=43.86 \times 0.20$ & $=66.41 \times 0.20$ & $\mathrm{SL}+\mathrm{LT}$ & $=43.86 \times 0.11$ & $=66.41 \times 0.11$ & $\mathrm{SL}+\mathrm{LT}$ & $=43.86 \times 0.11$ & $=66.41 \times 0.11$ \\
\hline & $\begin{array}{l}\text { Medium forwarder }(\mathrm{SL}) \\
=0.0030 \times \mathrm{fd}(\mathrm{m}) \\
+4.15\end{array}$ & $\begin{array}{l}\text { Medium forwarder }(\mathrm{SL}) \\
=0.0055 \times \mathrm{fd}(\mathrm{m})+ \\
7.51\end{array}$ & & $\begin{array}{l}\text { Medium harvester } \\
\text { (LT) } \\
=43.86 \times 0.10\end{array}$ & $\begin{array}{l}\text { Medium harvester } \\
\text { (LT) } \\
=66.41 \times 0.10\end{array}$ & & $\begin{array}{l}\text { Medium harvester } \\
\text { (LT) } \\
=43.86 \times 0.10\end{array}$ & $\begin{array}{l}\text { Medium harvester } \\
\text { (LT) } \\
=66.41 \times 0.10\end{array}$ \\
\hline & $\begin{array}{l}\text { Medium forwarder }(\mathrm{PL}) \\
=0.0032 \times \mathrm{fd}(\mathrm{m}) \\
+4.15\end{array}$ & $\begin{array}{l}\text { Medium forwarder }(\mathrm{PL}) \\
=0.0057 \times \mathrm{fd}(\mathrm{m})+ \\
7.50\end{array}$ & & $\begin{array}{l}\text { Medium forwarder } \\
(\mathrm{SL}) \\
=0.0030 \times \mathrm{fd}(\mathrm{m}) \\
+4.13\end{array}$ & $\begin{array}{l}\text { Medium forwarder } \\
(\mathrm{SL}) \\
=0.0055 \times \mathrm{fd}(\mathrm{m})+ \\
7.48\end{array}$ & & $\begin{array}{l}\text { Medium forwarder } \\
(\mathrm{SL}) \\
=0.0030 \times \mathrm{fd}(\mathrm{m}) \\
+4.13\end{array}$ & $\begin{array}{l}\text { Medium forwarder } \\
(\mathrm{SL}) \\
=0.0055 \times \mathrm{fd}(\mathrm{m})+ \\
7.48\end{array}$ \\
\hline & $\begin{array}{l}\text { Timber truck and trailer } \\
\text { (SL) } \\
=338 \times[0.054+(0.005 \times \operatorname{td}( \\
\left.\left.\mathrm{km})^{-0.278}\right) \times \operatorname{td}(\mathrm{km})\right]\end{array}$ & $\begin{array}{l}\text { Timber truck and trailer } \\
(\mathrm{SL}) \\
=[(9.70 \times 2 \times \mathrm{td}(\mathrm{km})) / 19.6] \\
+(178 / 19.6)\end{array}$ & & $\begin{array}{l}\text { Medium forwarder } \\
(\mathrm{LT}) \\
=0.0027 \times \mathrm{fd}(\mathrm{m}) \\
+4.40\end{array}$ & $\begin{array}{l}\text { Medium forwarder } \\
\text { (LT) } \\
=0.0049 \times \mathrm{fd}(\mathrm{m})+ \\
7.96\end{array}$ & & $\begin{array}{l}\text { Medium forwarder } \\
(\mathrm{LT}) \\
=0.0027 \times \mathrm{fd}(\mathrm{m}) \\
+4.40\end{array}$ & $\begin{array}{l}\text { Medium forwarder } \\
(\mathrm{LT}) \\
=0.0049 \times \mathrm{fd}(\mathrm{m})+ \\
7.96\end{array}$ \\
\hline & $\begin{array}{l}\text { Timber truck and trailer } \\
\text { (PL) } \\
=36.74 \times[0.055+(0.005 \times \mathrm{t} \\
\left.\left.\mathrm{d}(\mathrm{km})^{-0.278}\right) \times \operatorname{td}(\mathrm{km})\right]\end{array}$ & $\begin{array}{l}\text { Timber truck and trailer } \\
(\mathrm{PL}) \\
=[(1.05 \times 2 \times \mathrm{td}(\mathrm{km})) / 18.8] \\
+(19.35 / 18.8)\end{array}$ & & $\begin{array}{l}\text { Timber truck and } \\
\text { trailer }(\text { SL) } \\
=36.74 \times[0.054+(0.005 \\
\left.\times \operatorname{td}(\mathrm{km})^{-0.278}\right) \times \\
\operatorname{td}(\mathrm{km})]\end{array}$ & $\begin{array}{l}\text { Timber truck and } \\
\text { trailer }(\mathrm{SL}) \\
=[(1.05 \times 2 \times \\
\operatorname{td}(\mathrm{km})) / 19.6] \\
+(19.35 / 19.6)\end{array}$ & & $\begin{array}{l}\text { Timber truck and } \\
\text { trailer (SL) } \\
=36.74 \times[0.054+(0.005 \\
\left.\times \operatorname{td}(\mathrm{km})^{-0.278}\right) \times \\
\operatorname{td}(\mathrm{km})]\end{array}$ & $\begin{array}{l}\text { Timber truck and trailer }(\mathrm{SL}) \\
=[(1.05 \times 2 \times \operatorname{td}(\mathrm{km})) / 19.6] \\
+(19.35 / 19.6)\end{array}$ \\
\hline & & & & $\begin{array}{l}\text { Logging residues truck } \\
\text { and trailer }(\mathrm{LT}) \\
=37.61 \times[0.074+(0.008 \\
\left.\times \operatorname{td}(\mathrm{km})^{-0.278}\right) \times \\
\operatorname{td}(\mathrm{km})]\end{array}$ & $\begin{array}{l}\text { Logging residues truck } \\
\text { and trailer }(\mathrm{LT}) \\
=[(1.20 \times 2 \times \\
\operatorname{td}(\mathrm{km})) / 13.5] \\
+(21.96 / 13.5)\end{array}$ & & $\begin{array}{l}\text { Logging residues truck } \\
\text { and trailer }(\mathrm{LT}) \\
=37.61 \times[0.074+(0.008 \\
\left.\times \operatorname{td}(\mathrm{km})^{-0.278}\right) \times \\
\operatorname{td}(\mathrm{km})]\end{array}$ & $\begin{array}{l}\text { Logging residues truck and } \\
\text { trailer }(\mathrm{LT}) \\
=[(1.20 \times 2 \times \operatorname{td}(\mathrm{km})) / 13.5] \\
+(21.96 / 13.5)\end{array}$ \\
\hline \multirow[t]{4}{*}{$\begin{array}{l}\mathrm{FF} \\
> \\
\mathrm{SL}+\mathrm{PL}\end{array}$} & $\begin{array}{l}\text { Large harvester }(\mathrm{SL} / \mathrm{PL}) \\
=47.51 \times 0.08\end{array}$ & $\begin{array}{l}\text { Large harvester } \\
(\mathrm{SL} / \mathrm{PL}) \\
=70.13 \times 0.08\end{array}$ & $\begin{array}{l}\mathrm{FF} \\
> \\
\mathrm{SPC}+\mathrm{SL} \\
+\mathrm{LT}\end{array}$ & $\begin{array}{l}\text { Feller-puller } \\
\text { (SPC+SL) } \\
=64.00 \times 0.06\end{array}$ & $\begin{array}{l}\text { Feller-puller } \\
\text { (SPC+SL) } \\
=96.00 \times 0.06\end{array}$ & $\begin{array}{l}\mathrm{FF} \\
> \\
\mathrm{SPC}+\mathrm{SL} \\
+\mathrm{LT}\end{array}$ & $\begin{array}{l}\text { Feller-puller } \\
\text { (SPC+SL) } \\
=64.00 \times 0.06\end{array}$ & $\begin{array}{l}\text { Feller-puller } \\
\text { (SPC+SL) } \\
=96.00 \times 0.06\end{array}$ \\
\hline & $\begin{array}{l}\text { Large forwarder (SL) } \\
=0.0026 \times \mathrm{fd}(\mathrm{m}) \\
+2.42\end{array}$ & $\begin{array}{l}\text { Large forwarder (SL) } \\
=0.0046 \times \mathrm{fd}(\mathrm{m})+ \\
4.24\end{array}$ & & $\begin{array}{l}\text { Feller-puller } \\
\text { (LT) } \\
=64.00 \times 0.02\end{array}$ & $\begin{array}{l}\text { Feller-puller } \\
(\text { LT) } \\
=96.00 \times 0.02\end{array}$ & & $\begin{array}{l}\text { Feller-puller } \\
\text { (LT) } \\
=64.00 \times 0.02\end{array}$ & $\begin{array}{l}\text { Feller-puller } \\
\text { (LT) } \\
=96.00 \times 0.02\end{array}$ \\
\hline & $\begin{array}{l}\text { Large forwarder }(\mathrm{PL}) \\
=0.0028 \times \mathrm{fd}(\mathrm{m}) \\
+3.15\end{array}$ & $\begin{array}{l}\text { Large forwarder }(\mathrm{PL}) \\
=0.0049 \times \mathrm{fd}(\mathrm{m})+ \\
5.51\end{array}$ & & $\begin{array}{l}\text { Large harvester } \\
(\mathrm{SPC}+\mathrm{SL}) \\
=47.51 \times 0.02\end{array}$ & $\begin{array}{l}\text { Large harvester } \\
(\mathrm{SPC}+\mathrm{SL}) \\
=70.13 \times 0.02\end{array}$ & & $\begin{array}{l}\text { Large harvester } \\
(\mathrm{SPC}+\mathrm{SL}) \\
=47.51 \times 0.02\end{array}$ & $\begin{array}{l}\text { Large harvester } \\
(\mathrm{SPC}+\mathrm{SL}) \\
=70.13 \times 0.02\end{array}$ \\
\hline & $\begin{array}{l}\text { Timber truck and trailer } \\
\text { (SL) }\end{array}$ & $\begin{array}{l}\text { Timber truck and trailer } \\
\text { (SL) }\end{array}$ & & $\begin{array}{l}\text { Large harvester } \\
\text { (LT) }\end{array}$ & $\begin{array}{l}\text { Large harvester } \\
\text { (SPC+SL) }\end{array}$ & & $\begin{array}{l}\text { Large harvester } \\
\text { (LT) }\end{array}$ & $\begin{array}{l}\text { Large harvester } \\
\text { (SPC+SL) }\end{array}$ \\
\hline
\end{tabular}




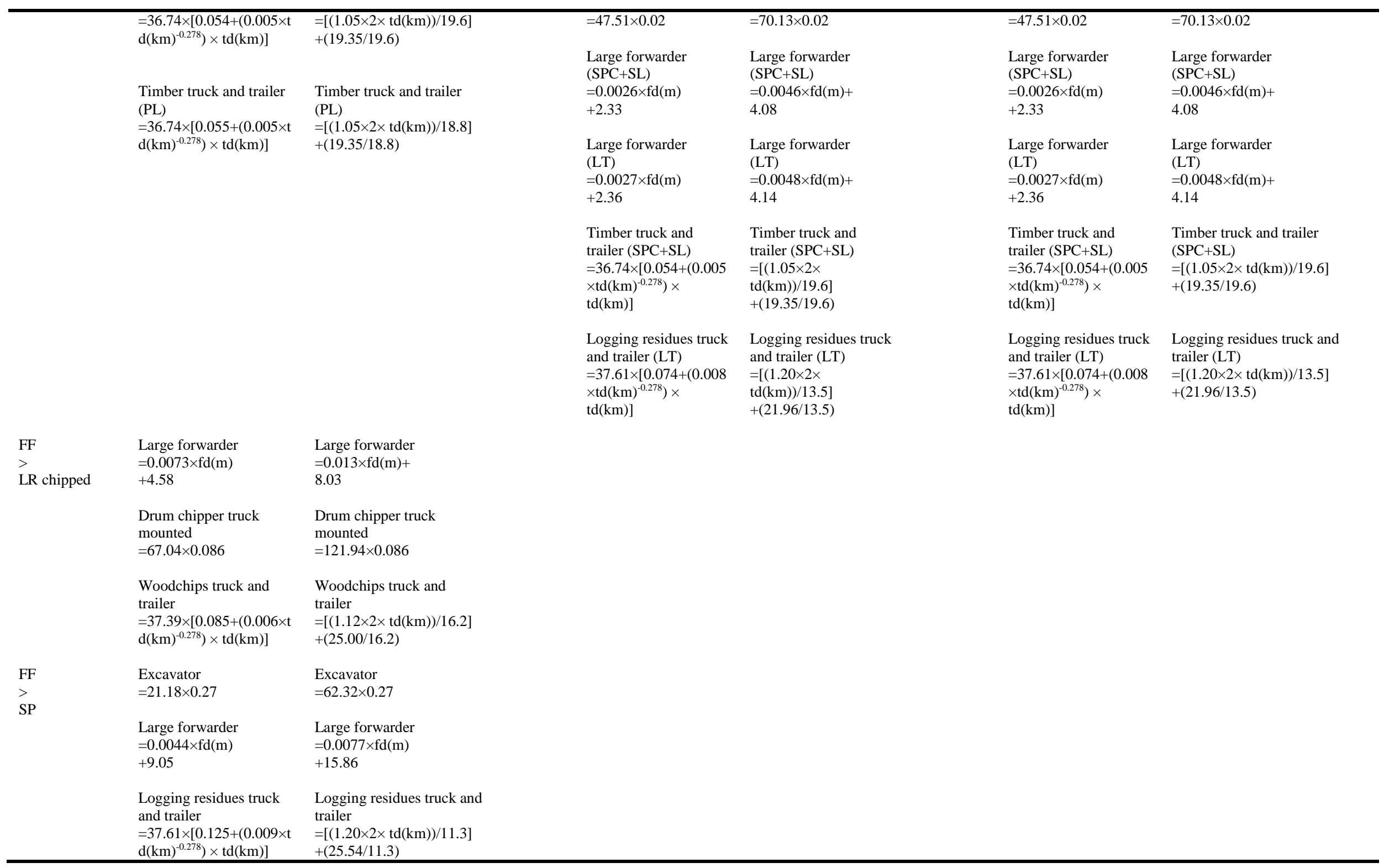




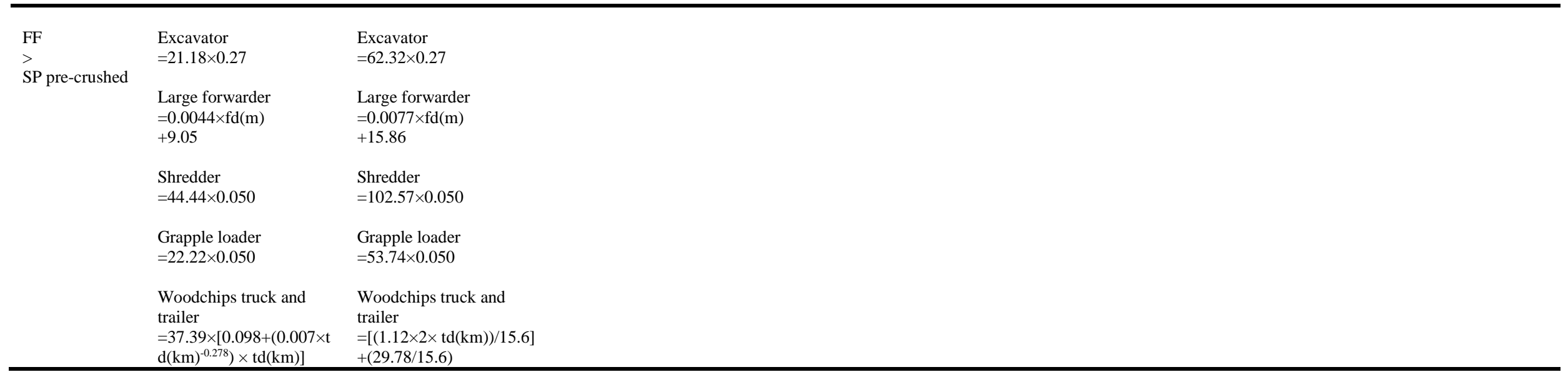


